\title{
Output Fluctuations in the G-7: An Unobserved Components Approach
}

\author{
Sinchan Mitra \\ Department of Economics \\ The University of Queensland \\ Brisbane, QLD 4072 \\ Australia \\ Email: smitra@uq.edu.au \\ Telephone: (617) 33656467
}

\author{
Tara M. Sinclair ${ }^{\dagger}$ \\ Department of Economics \\ The George Washington University \\ Washington, DC 20005 \\ USA \\ Email: tsinc@gwu.edu \\ Telephone: (202) 994-7988
}

\section{A revised version of this paper is forthcoming in Macroeconomic Dynamics.}

\author{
JEL Classifications: C32, E32, 057
}

Keywords: Trend-Cycle Decompositions, Business Cycles, Correlations, Real GDP

\begin{abstract}
This paper proposes a multivariate unobserved components model to simultaneously decompose the real GDP for each of the G-7 countries into their respective trend and cycle components. In contrast to previous literature, our model allows for explicit correlation between all the contemporaneous trend and cycle shocks. We find that all the G-7 countries have highly variable stochastic permanent components for output, even once we allow for structural breaks. We also find that common restrictions on the correlations between trend and cycle shocks are rejected by the data. In particular, we find that correlations across permanent and transitory shocks are important both within and across countries.

\footnotetext{
† Corresponding author: tsinc@gwu.edu. The authors wish to thank Shaghil Ahmed, Cigdem Akin, Gaetano Antinolfi, Tino Berger, Paul Carrillo, Yoosoon Chang, Marcelle Chauvet, Brian Doyle, Shahe Emran, Gerdie Everaert, Steve Fazzari, Etienne Gagnon, Ed Greenberg, Jean Imbs, Juan-Angel JimenezMartin, Fred Joutz, Ayhan Kose, James Morley, Chris Otrok, Bruce Petersen, Roberto Sameniego, Herman Stekler, Tatsuma Wada, and Eric Zivot for helpful comments. We also thank the participants in the Applied Time Series Research Group at Washington University in St. Louis; the Macro-International Seminar at George Washington University; the SNDE 2007 meetings in Paris; the SHERPPA seminar at the University of Ghent, Belgium; the CeMENT workshop in New Orleans; the International Finance Seminar at the Federal Reserve Board; the economics seminar at the Universidad Complutense in Madrid; the Macroeconomics Seminar at the University of Munich; the $5^{\text {th }}$ Eurostat Colloquium on Modern Tools for Business Cycle Analysis; and the seminar at the Zentrum für Europäische Wirtschaftsforschung (ZEW) in Mannheim, Germany. We thank Jahangir Hossain, Kavita Patel, Amr Moubarak, Aashna Sinha, and Alex Wong for excellent research assistance. We also thank two anonymous referees for comments that helped improve the paper. Generous support for this project was provided by the Institute for International Economic Policy at the Elliott School of International Affairs. All remaining errors are our own.
} 


\section{Introduction}

The debate about the nature of economic fluctuations has long been at the center of macroeconomic research. One critical issue is whether the business cycle is wholly transitory, or whether it might be "real" in the sense that it is characterized primarily by permanent rather than transitory movements. ${ }^{1}$ Research addressing this issue has generally focused on the U.S., but there has been increasing interest in cross-country comparisons as well (e.g. Cogley, 1990; Backus, Kydland and Kehoe, 1992; Canova and de Nicolo, 2003). Another subject that has received attention recently is the linkage of economic activity across countries. Research on international business cycles has documented international co-movements in a wide array of macroeconomic variables (e.g. Backus, Kydland, and Kehoe, 1992; Gregory, Head, and Raynauld, 1997; and Kose, Otrok and Whiteman, 2003).

This paper proposes a multivariate unobserved components model to examine the role of permanent or "trend" shocks versus transitory or "cycle" shocks as sources of variation in real GDP across the G-7 countries from 1960 through 2009. With this model we simultaneously decompose the real GDP for each of the G-7 countries into their unobserved permanent and transitory components. Cross-country evidence should be helpful to ascertain business cycle characteristics as there are commonalities in the behavior of real quantities across countries (Diebold and Rudebusch, 1996). We thus use the variation across countries to identify the parameters for each individual series in order to improve the efficiency of the estimates. Furthermore, we build on the model of

\footnotetext{
${ }^{1}$ For a discussion of this debate, see Kim, Piger, and Startz (2007). Throughout this paper we use the term "business cycle" to refer generally to economic fluctuations. This is in line with the definition that the NBER and the CEPR business cycle dating committees use, according to Harding and Pagan (2005). For an alternative approach relating the phases of business cycle movements in the G-7, see Chauvet and $\mathrm{Yu}$ (2006).
} 
Morley, Nelson, and Zivot (2003), and allow for explicit interaction between permanent and transitory shocks. We are thus able to jointly address three major macroeconomic questions: 1) Are fluctuations in output primarily due to permanent or transitory movements? 2) Is the relative importance of permanent versus transitory movements in output similar across countries? 3) What is the pattern of correlation between the permanent and transitory movements in output across the G-7 countries?

This paper employs a multivariate correlated unobserved components model in order to consider these questions. Prior research has explored the role of permanent and transitory shocks in a single real GDP series using a univariate correlated unobserved components model (e.g. Basistha, 2007, for Canada; Morley, Nelson, and Zivot, 2003, for the U.S.). Multiple series relationships for the same country have been explored as well in an unobserved components framework (e.g. Basistha, 2007, for Canadian output and inflation; Morley, 2007, for U.S. consumption and income; Sinclair, 2009, for U.S. output and the unemployment rate). There has also been a significant amount of research examining cross-country relationships using various empirical models (e.g. Kose, Otrok and Whiteman, 2003, and references therein). The novelty of this paper is to estimate a multivariate correlated unobserved components model using data from several countries and explore the interactions among their permanent and transitory shocks.

The majority of previous studies that have considered international output comovements have used detrended or first-differenced data. One benefit of our approach is that it does not require a prior transformation of the GDP series. Common detrending methods, such as the Hodrick Prescott filter and bandpass filters, are known to produce spurious cycles for nonstationary data, such that the results are sensitive to the detrending 
method that is chosen (Cogley and Nason, 1995; Murray 2003; Doorn 2006). Firstdifferencing can avoid the problem of the spurious cycle for difference-stationary data, but then the permanent and transitory components cannot be separated without additional identification assumptions. Our approach, however, allows us to estimate the permanent and transitory components jointly as well as the relationships between them.

Our model also places fewer restrictions on the relationships across countries than in several other studies. Dynamic factor models, for example, often assume there is a single common world factor, which may lead to attributing all cross-country relationships to the "world shock" (see discussion in Stock and Watson, 2005). Our empirical framework avoids imposing a common dynamic factor structure on all countries prior to estimation. It is also not necessary to assume common trends or common cycles for identification (see Centoni, Cubadda, and Hecq, 2007; Vahid and Engle, 1993, 1997), though our framework still accommodates potential commonalities (Everaert, 2007; Schleicher, 2003). Finally, we are able to directly use the estimated correlation matrix to examine the cross-country relationships, instead of estimating the correlations in a second stage using the estimated components.

To preview our results, we find that permanent shocks play an important role for the real GDP of all seven countries, even after allowing for structural breaks. We also find that permanent and transitory shocks within each series are negatively correlated. One interpretation of our results is that each economy is frequently buffeted by permanent shocks. Observed output, however, takes time to adjust to the changing steady state, resulting in the contemporaneous negative correlation between permanent and transitory shocks within each series. 
With regards to the cross-country relationships, we find that we cannot neglect the cross-country, permanent-transitory correlations, i.e. the correlations between permanent shocks to country $i$ and transitory shocks to country $j$. If we restrict these correlations to be equal to zero then we would conclude that the G-7 countries are mostly connected through their permanent shocks. The data reject this restriction, however, in favor of a more complicated relationship across countries where there are also shocks that appear to have permanent effects in some countries while temporary effects in others.

The rest of the paper proceeds as follows. In Section 2 we present the multivariate correlated unobserved components model. In Section 3 we discuss the data and the results. In Section 4 we conclude.

\section{The Model}

The output for each country can be represented as the sum of a stochastic "trend" component and a "cycle" component. The "trend" $(\tau)$, also called the permanent component, is the steady-state level after removing all temporary movements from the series. The "cycle" (c), also called the transitory component, embodies all temporary movements and is assumed to be the stationary remainder after removing the trend component:

$$
y_{i t}=\tau_{i t}+c_{i t}, i=1 \text { to } 7 \text { for each country }
$$

A random walk for each of the trend components allows for permanent movements in the series. We also allow for a drift $(\mu)$ in the trend:

$$
\tau_{i t}=\mu_{i}+\tau_{i t-1}+\eta_{i t}
$$


According to Perron and Wada (2009), including a structural break in the trend may be important for proper estimates of the variability of the permanent component. They find that a break occurred in 1973:1 for the U.S. Moreover, an extensive literature indicates that there was a productivity slowdown in all the G-7 countries at about that time (Ben-David and Papell, 1998; Bai, Lumsdaine, and Stock, 1998). We, therefore, tested each series separately for structural breaks in the drift (Andrews, 1993, and Bai and Perron, 1998). Univariate break tests find structural breaks in the drift terms for all seven countries somewhere in the early 1970s and an additional break for Japan in 1991Q3. We incorporate these structural breaks into our estimates and will discuss this further below in section 3.2. ${ }^{2}$

We model each transitory component as a second order autoregressive process, $\operatorname{AR}(2)$ :

$$
c_{i t}=\phi_{1 i} c_{i t-1}+\phi_{2 i} c_{i t-2}+\varepsilon_{i t}
$$

In general, AR(2) dynamics are sufficient for identification (Morley, Nelson, and Zivot, 2003; Sinclair, 2009). Univariate specification tests were performed which suggested that an AR(2) model for each individual country would be appropriate. Further discussion of the AR(2) assumption is included in Section 3.3.

We assume the shocks $\left(\eta_{i t}\right.$, and $\left.\varepsilon_{i t}\right)$ are normally distributed, mean zero, random variables with a general covariance matrix (allowing possible correlation between any of the contemporaneous shocks to the unobserved components). The two key identifying assumptions of this model are that the permanent component is a random walk with drift

\footnotetext{
${ }^{2}$ Another alternative would be to use the mixture of normals approach as discussed in Wada and Perron (2006).
} 
and that the remaining stationary part has only autoregressive dynamics (but the reduced form growth rates also have MA dynamics).

The key difference between our model and a traditional unobserved components model is in the variance-covariance matrix for the permanent and transitory shocks:

$$
E\left(\left[\begin{array}{l}
\eta_{t} \\
\varepsilon_{t}
\end{array}\right]\left[\begin{array}{ll}
\eta_{t} & \varepsilon_{t}
\end{array}\right]\right)=\left[\begin{array}{cc}
\Sigma_{\eta} & \Sigma_{\eta \varepsilon} \\
\Sigma_{\varepsilon \eta} & \Sigma_{\varepsilon}
\end{array}\right],
$$

where $\Sigma_{\eta}$ is the $7 \times 7$ variance-covariance matrix for the shocks to the permanent components:

$$
\Sigma_{\eta}=\left[\begin{array}{cccc}
\sigma_{\eta 1}^{2} & \sigma_{\eta 1 \eta 2} & \cdots & \sigma_{\eta 1 \eta 7} \\
\sigma_{\eta 1 \eta 2} & \sigma_{\eta 2}^{2} & \cdots & \sigma_{\eta 2 \eta 7} \\
\vdots & \vdots & \ddots & \vdots \\
\sigma_{\eta 1 \eta 7} & \sigma_{\eta 2 \eta 7} & \cdots & \sigma_{\eta 7}^{2}
\end{array}\right],
$$

$\Sigma_{\varepsilon}$ is the $7 \times 7$ variance-covariance matrix for the shocks to the transitory components:

$$
\Sigma_{\varepsilon}=\left[\begin{array}{cccc}
\sigma_{\varepsilon 1}^{2} & \sigma_{\varepsilon 1 \varepsilon 2} & \cdots & \sigma_{\varepsilon 1 \varepsilon 7} \\
\sigma_{\varepsilon 1 \varepsilon 2} & \sigma_{\varepsilon 2}^{2} & \cdots & \sigma_{\varepsilon 2 \varepsilon 7} \\
\vdots & \vdots & \ddots & \vdots \\
\sigma_{\varepsilon 1 \varepsilon 7} & \sigma_{\varepsilon 2 \varepsilon 7} & \cdots & \sigma_{\varepsilon 7}^{2}
\end{array}\right],
$$

and $\Sigma_{\eta \varepsilon}=\Sigma_{\varepsilon \eta}$ ' represents the cross-covariance terms between the permanent and transitory shocks, where we refer to the off-diagonal terms as the cross-country, permanent-transitory covariances and the diagonal terms as the within-series covariances:

$$
\Sigma_{\eta \varepsilon}=\left[\begin{array}{cccc}
\sigma_{\eta 1 \varepsilon 1} & \sigma_{\eta 1 \varepsilon 2} & \cdots & \sigma_{\eta 1 \varepsilon 7} \\
\sigma_{\eta 2 \varepsilon 1} & \sigma_{\eta 2 \varepsilon 2} & \cdots & \sigma_{\eta 2 \varepsilon 7} \\
\vdots & \vdots & \ddots & \vdots \\
\sigma_{\eta 7 \varepsilon 1} & \sigma_{\eta 7 \varepsilon 2} & \cdots & \sigma_{\eta 7 \varepsilon 7}
\end{array}\right],
$$


Traditionally, unobserved components models have imposed restrictions on the variance-covariance matrix. Generally they have assumed that the off-diagonal elements of (4) were equal to zero, or at least that (4c) was a matrix of zeros. Our model, however, imposes no restrictions on the variance-covariance matrix and thus we have estimates for all potential contemporaneous within-series and across-series correlations.

We cast the model into state-space form (available from the authors upon request) and apply the Kalman filter for maximum likelihood estimation (MLE) of the parameters using prediction error decomposition and to estimate the permanent and transitory components. ${ }^{3}$

\section{The Data and Results}

We apply the model of Section 2 to output data for the G-7 countries; namely Canada, France, Germany, Italy, Japan, the U.K., and the U.S. The data are quarterly observations on real GDP from 1960:1 to 2009:4 from OECD Quarterly National Accounts. ${ }^{4}$

Table 1 reports the maximum likelihood estimates of our multivariate correlated unobserved components model. Model 1 allows for the general covariance matrix and includes a structural break in the drift term in early 1970s for all countries, and an additional structural break for Japan in the third quarter of $1991 .{ }^{5}$ The remaining two

\footnotetext{
${ }^{3}$ See chapter 3 of Kim and Nelson (1999a) or chapter 4 of Harvey (1993) for a discussion of the implementation of the Kalman filter. All estimation was done in GAUSS version 6.0. To ensure that the estimates represent the global maximum, estimates of all models were repeated using different starting values approximating a coarse grid search. The appropriateness of MLE in the case of random walk components has been examined in Chang, Miller, and Park (2009).

${ }^{4}$ Specifically we downloaded the following data for all seven countries from OECD.Stat: VOBARSA: Millions of national currency, volume estimates, OECD reference year, annual levels, seasonally adjusted (downloaded on March 3, 2010).

${ }^{5}$ Based on univariate unknown structural break date tests, the structural breaks were in the second quarter of 1973.2 for the U.S., U.K., Japan, and Germany and in second quarter of 1974 for Canada, France, and Italy.
} 
columns of Table 2 report restricted models. Model 2 presents results restricting the cross-correlation matrix, $\Sigma_{\eta \varepsilon}$. to be a matrix of zeros. Model 3 allows for the general covariance matrix, but does not include structural breaks. Models 2 and 3 are both rejected in favor of Model 1 based on likelihood ratio tests with p-values less than 0.01 in both cases. ${ }^{6}$ For each country, Figure 1 presents the estimated components based on Model 1 along with the corresponding real GDP series.

\subsection{The Estimated Components}

Based on the seven panels of Figure 1, the estimated permanent components are clearly variable. In fact, if we compare the standard deviations of the permanent shocks (presented in the first column of Table 1c and discussed further in section 3.4) with that of the growth rate of real GDP for each country, we find that the permanent shocks have larger standard deviations than the standard deviation of real GDP growth for all seven countries. The permanent components can be more volatile than the series itself because we find, as we discuss further in Section 3.5, that there is negative correlation between permanent and transitory shocks for all of the G-7 countries. Given the variability of the permanent components, the transitory components may not completely capture the traditional "cycle.”" The shaded regions in Figure 1 represent recessions (i.e. business cycle peak to trough periods), based on dates provided by the Economic Cycle Research Institute (ECRI), except for the U.S. where the dates come from the National Bureau of

\footnotetext{
${ }^{6}$ It is particularly striking that based on restricted Model 2, which does not all for correlation between the permanent and transitory shocks, that the estimates for the autoregressive parameters for several countries appear implausible. For example, the estimated AR parameters for Germany are negative and for Italy they are both near zero. This suggests that Model 2 is imposing inappropriate restrictions.

${ }^{7}$ Japan and the U.K. appear to have the most volatile components (confirmed by the estimates of the standard deviations of their shocks). As discussed in Section 3.3, we may want to take these two estimates with some caution because the estimates of their second autoregressive parameters do not appear to be statistically significant, which is necessary for identification.
} 
Economic Research (NBER). There is clear peak to trough movement for most recessions in the transitory components, but the permanent components also appear to decline during most recessions. ${ }^{8}$ In further discussion in Section 3.5, we interpret some of the movements of the transitory component as being adjustments to the permanent shocks, although other interpretations are possible.

\subsection{The Drift Terms}

Table 1a presents the drift terms for our estimated models. Based on the estimates from Model 1, the post-1970s drift term is found to be smaller than that of the pre-1970s sample for all seven countries, further supporting the productivity slowdown hypothesis for the G-7 countries. ${ }^{9}$

We also considered whether there were structural breaks associated with other important developments that occurred during our sample period. The only other significant structural break that we found was for Japan in the third quarter of 1991 . The smaller drift term after the third quarter of 1991 for Japan is consistent with the slower economic growth that Japan has experienced since the early 1990s.

\footnotetext{
${ }^{8}$ In an elegant paper applying generalized method of moments to a rational expectations aggregate demand/aggregate supply model of the output growth and inflation of France , Germany, Italy, the Netherlands, the U.K. and the U.S., Hartley and Whitt (2003) found that it is actually permanent demand shocks that have been the dominant source of variance in output growth in several of the countries in their sample. Therefore, we are careful not to interpret our permanent components as capturing only supply shocks.

${ }^{9}$ Papanyan (2007) models the G-7 countries with a common permanent component. She finds that this component experiences a one-time switch from a high-growth regime to a low-growth regime in the second quarter of 1973, which is consistent with our structural breaks occurring in the early 1970s.
} 


\subsection{The Autoregressive Parameters}

Table 1b presents the AR parameters for our estimated models. The autoregressive coefficients reflect the dynamics of the transitory components. It is important to emphasize that the transitory components are simply the stationary part of the data, as identified from the model presented in Section 2.1. Our estimates suggest that a substantial amount of the fluctuations in real GDP occur in the permanent components, so movements in the transitory components do not necessarily match the traditional notion of the "cycle." For example, for some of the countries in our sample (Canada, Japan, and the U.K.) the autoregressive process in the transitory component does not have complex roots, suggesting that these components do not have the periodic characteristic of a "cycle."

The sum of the autoregressive coefficients provides a measure of persistence of the transitory components. Focusing on our preferred model, Model 1, all countries appear to have quite persistent transitory components, ranging from a sum of 0.80 for Germany to 0.91 for both the U.K. and Canada. None of these results appear to be outside the range of previous estimates. Most importantly, these are not at the boundary where the transitory component might appear nonstationary.

Since one of the key assumptions of identification is that the transitory component contains at least $\mathrm{AR}(2)$ dynamics, it is important to investigate this assumption. As discussed in Morley, Nelson, and Zivot (2003), an AR(p) transitory component corresponds to an $\operatorname{ARMA}(p, p)$ for the reduced form (i.e. the growth rate). Therefore, we first estimated ARMA models for the growth rates of the seven series individually. Based on the Akaike Information Criterion (AIC), all countries have at least $\operatorname{ARMA}(2,2)$ 
dynamics for their real GDP growth rate. For several countries the AIC indicated longer lags might be appropriate. We therefore also estimated an AR(4) model and found that additional lags did not qualitatively change the results. We thus reported the parsimonious $\operatorname{AR}(2)$ results. Upon examining the AR(2) estimates, however, it appears that according to our preferred model, Model 1, the second AR coefficient is not significant for the U.K. or for Japan. We therefore also estimated a model for the 5 remaining countries and found that the results for those countries remained consistent with our conclusions based on the G7 model. We may, however, take the results for the U.K. and Japan with a bit of caution.

\subsection{The Permanent and Transitory Standard Deviations}

The estimates based on Model 1 suggest a large role for permanent movements. In fact, the standard deviation for the innovation to the permanent component exceeds the standard deviation for the innovation to the transitory component for five of the seven countries (Canada, France, Germany, Italy, and the U.S.). In addition, the permanent shocks have a larger standard deviation than the standard deviation of real GDP growth (defined as the first difference in the natural log of real GDP times 100) for all seven countries.

It is interesting here to compare the results of the restricted models with Model 1. Column 2 presents estimates of a traditional unobserved components model which assumes that there is only correlation between permanent shocks and correlation between transitory shocks, with no correlation across permanent and transitory shocks (either within series or across countries) This restriction results in lower estimates of standard 
deviations for both permanent and transitory movements than does the fully correlated UC model for all seven countries. Restricting the correlation between permanent and transitory shocks to be zero is implicitly restricting the volatility of both components. In the case where the correlation between permanent and transitory shocks is negative, each component can potentially be more volatile than the series itself. Based on our estimates, the restriction of zero correlation between permanent and transitory shocks is rejected by the data for all the G7 countries in favor of negative correlation, so the finding of higher standard deviations for both permanent and transitory shocks is not surprising.

In terms of the role of structural breaks in the estimates of the standard deviations of the shocks, we can compare Model 3, which excludes structural breaks, with Model 1. Based on this comparison, there is not a clear pattern on the standard deviations of the shocks by including structural breaks. For five of the seven countries the standard deviation of the permanent shock is larger without structural breaks, but for two, Canada and the U.S., the estimate is larger in the case including structural breaks. A similar pattern occurs for the transitory shocks where the standard deviations are smaller with structural breaks for four countries, but about the same in the case of Canada and larger for both the U.K. and the U.S. What is important to note, however, is that we still find a clear role for permanent shocks even after incorporating structural breaks. This is in contrast to the finding based on univariate models. For example, Perron and Wada (2009) find that U.S. real GDP becomes trend-stationary after accounting for a break in the drift term. Basistha (2007) estimates a model similar to Perron and Wada for Canada and also finds that the trend becomes almost non-stochastic. Our results are, however, consistent with findings from other multivariate models. Basistha (2007) found that 
permanent shocks were important for Canadian real GDP once he expanded his model into a bivariate model by adding inflation. Similarly, Sinclair (2009) found an important role for permanent shocks in a bivariate model of U.S. real GDP and the unemployment rate even after incorporating structural breaks. Our estimates present further evidence that incorporating structural breaks does not remove the role for permanent shocks once we take advantage of information provided by using data series from multiple countries.

\subsection{The Within-Series Relationships}

The correlations between the permanent and transitory shocks within each series are found to be significantly negative for all seven countries, whether or not we include structural breaks in the drift term, as can be seen Table 1d. Based on Model 1, these estimates range from -0.78 for the U.S. to -0.99 for Canada. These results are consistent with prior research that has examined the correlation between permanent and transitory shocks for the real GDP of the U.S. (Morley, Nelson, and Zivot, 2003), Canada (Basistha, 2007), the U.S. and the U.K. (Nagakura, 2008), and six of the seven G-7 countries (excluding Japan, Nagakura, 2007). All of these models found that the correlation between the permanent and transitory shocks for real GDP is significantly negative. Berger (forthcoming), however, finds that the within series correlations are in general close to zero and insignificant for a multivariate model of output, unemployment, and inflation for aggregated euro area data. By contrast, in our multiple-country model we find that the negative correlation between the permanent and transitory shocks in real GDP is robust to multivariate modeling and is similar across the G-7 countries. 
One interpretation of the negative correlation between the permanent and transitory shocks is that it is due to a dominance of shocks which shift permanent GDP today, but with slow adjustment of actual GDP to the steady-state level (see, for example, Stock and Watson, 1988; Morley, Nelson, and Zivot, 2003; Morley, 2007; and Sinclair, 2009). Slow adjustment of the series to permanent shocks would result in negative contemporaneous correlation since the difference between the series and the permanent component is negative in the case of a positive permanent shock. Two potential sources of the slow adjustment have been previously emphasized in the literature. Blanchard and Quah (1989) suggest that the pattern arises from supply shocks combined with nominal rigidities, such as imperfectly flexible prices. Real business cycle theories, such as those of Prescott (1987) and Kydland and Prescott (1982), instead emphasize "time-to-build.” They suggest that it may take more than one period for the construction of new productive capital in response to real shocks. Our results are consistent with either of these interpretations. Either interpretation requires frequent permanent shocks and is thus supported by the variable stochastic permanent component estimated for each of the countries.

There are other theories, however, which can potentially explain the negative correlation between the innovations to the unobserved components of GDP. One example would be the "creative destruction" hypotheses. According to this view, recessions are times of cleansing when outdated or unprofitable techniques are pruned out of the productive system. A related idea is the pit-stop view of recessions according to which recessions are times when productivity improving activities are undertaken because of their temporarily low opportunity costs (Caballero and Hammour 1994). Both of these 
theories would imply a negative correlation between innovations to the within-series components. However, the dynamic behavior of our estimated permanent and transitory components during expansions and recessions suggest that a large part of the transitory movements in the series arise from adjustment to permanent changes, rather than viceversa.

Another theory is that the negative correlation is arising due to model misspecification. This may be due to misspecification of the structural breaks (Perron and Wada, 2009) or more general misspecification of the process that might be better captured by a mixture of normals (Wada and Perron, 2006) or a generalized trend (Ma and Wohar, 2009). Based on our estimates including structural breaks, we still find a role for significant variation in the permanent component and for negative within series correlation. This finding suggests it is not neglected drift breaks alone which explain the negative within series correlation. ${ }^{10}$ Our results remain sensitive to model specification, however our model is more general in several respects than most previous models of real GDP. Evidence from our estimates suggests that the correlation between permanent and transitory shocks is important for modeling the real GDP of the G-7 countries.

\footnotetext{
${ }^{10}$ We also considered the impact on our results of the significant decrease in volatility in U.S. output growth around 1984 known as the "Great Moderation," (documented initially in the U.S. by Kim and Nelson, 1999b, and McConnell and Perez Quiros, 2000, and in the other countries of the G-7 by Mills and Wang, 2003, and van Dijk, Osborn, and Sensier, 2002). Due to the number of parameters in our model, neither sub-sample analysis nor a complete break in the covariance matrix is possible. We do find, however, that our results are robust to allowing for a one-time break in the variances. We do this by adding seven additional parameters to the state-space model, assuming that the correlations stay the same and that the proportional size of the break is the same for the permanent and transitory components. Support for our choice of a proportional change in the matrix comes from Doyle and Faust (2005) who cannot reject the hypothesis that correlation has remained the same across the G-7 countries. Ahmed, Levin, and Wilson (2004) provide additional support for our choice of modeling, at least for the U.S. They find that they cannot reject the hypothesis that the reduction in volatility in U.S. real GDP growth is proportional across all frequencies. They interpret this result to suggest that the volatility reduction is primarily due to a reduction in innovation variance.
} 


\subsection{The Cross-Country Relationships}

Using the multivariate unobserved components model, we are able to identify and estimate the cross-country correlations between the permanent shocks $\left(\sigma_{\eta i \eta j}\right)$, the transitory shocks $\left(\sigma_{\varepsilon i \varepsilon j}\right)$, and the permanent and transitory shocks $\left(\sigma_{\eta i \varepsilon j}\right) .{ }^{11}$ We simultaneously estimate the correlation between the shocks when estimating the components. This is an improvement over the conventional method of estimating the components and then estimating their correlation in a second stage. Studying the estimate of the correlation rather than the correlation of the estimates allows us to avoid potential measurement error and spurious results arising from detrending methods. Based on the estimated correlations between the permanent and transitory shocks across countries listed in Tables 1e through 1g, we find that both permanent and transitory shocks are important in driving international co-movements. In particular, it appears important that we allow for correlation between the permanent shocks and the transitory shocks. The estimates clearly reject the restriction (imposed in Model 2) that the $\Sigma_{\eta \varepsilon}$ matrix is a zero matrix in favor of the unrestricted estimates from Model 1. This result is not simply due to the importance of within-series correlations. We also estimated a model where the $\Sigma_{\eta \varepsilon}$ matrix was restricted to be a diagonal matrix. This model was also rejected in favor of the unrestricted estimates from Model 1 with a p-value for the likelihood ratio test statistic of less than 0.01. In fact, comparing the additional restrictions of Model 2 with the diagonal matrix model led to a p-value of the likelihood ratio test statistic of 0.08 . Thus the correlations between permanent and transitory shocks across countries appear important to the estimates.

\footnotetext{
${ }^{11}$ For a discussion of the co-movements among the growth rates of the G-7 countries, see Doyle and Faust (2002, 2005).
} 
The finding that we cannot restrict the permanent-transitory correlations to be zero means that we cannot directly decompose the relationships across countries into those due to the correlation among permanent shocks versus those due to temporary shocks. There are, however, a few key patterns to discuss. First, we can compare the results across the three models reported in Table 1. Comparing Model 3, which excludes structural breaks in the drift term, with Model 1 suggests that the structural breaks reduce the estimated size of most of the correlations across countries for both permanent shocks and for transitory shocks. It is clear that the structural break that occurred at approximately the same time for all of these countries results in their growth rates appearing more correlated than once we take this structural break into account.

The key results, however, become clearer when we compare Model 2, where we restrict the $\Sigma_{\eta \varepsilon}$ matrix to be zero, with our general Model 1. If we estimate a more traditional unobserved components model, i.e. Model 2, where we restrict the cross country correlations to be only permanent or temporary, with no permanent-transitory correlations, then we would conclude that the G-7 countries are mostly connected through their permanent shocks. We find, however, that the data reject this restriction in favor of a more complicated relationship across countries where there are also shocks that are permanent in some countries while temporary in others, as presented in Model 1. We find that almost all of the correlations between the permanent components across countries are smaller once we allow for cross country permanent-transitory correlation. On the other hand, for the correlations between the transitory components, the estimates are larger in general in the case of Model 1 compared to Model 2. ${ }^{12}$

\footnotetext{
${ }^{12}$ This finding of complicated cross-country interconnectedness does not, however, contradict the finding of Crucini, Kose and Otrok (2008) that "the source of the international business cycle is primarily driven by
} 
Our results have implications regarding the potential for international output risk sharing among the G-7 countries. The low correlations across permanent and transitory shocks that we find may suggest the existence of a large pool of risks that can be effectively insured. However, our results indicate that permanent shocks are a major driver of output variability in these economies. Many recent papers in the literature (Baxter and Crucini, 1995; Asdrubali, Sorensen and Yosha, 1996; Sorensen and Yosha, 1998; Becker and Hoffman, 2006) argue that insurance against permanent output shocks are much harder to achieve, especially across countries. This is because insurance against such shocks requires the use of state-contingent assets such as e.g. equity whereas transitory shocks can be smoothed through the use of credit markets such as e.g. loans and bonds alone (Baxter and Crucini, 1995). Becker and Hoffman (2006) find that while insurance against transitory fluctuations in output is virtually complete for OECD countries, it is nearly non- existent for permanent shocks. They conclude that various forms of endogenous market incompleteness make permanent shocks more difficult to insure, particularly at the international level.

\subsection{The Recession of $2007-2009$}

According to the Economic Cycle Research Institute (ECRI), all seven countries experienced a business cycle peak somewhere near the end of our sample, with Italy having the earliest peak in August of 2007 and Germany having the latest peak in April of 2008. For four of the seven countries, by February, 2010, the ECRI had also already indicated a trough within our sample, occurring as early as January 2009 for Germany

productivity.” As discussed in Lippi and Reichlin (1994), we cannot interpret innovations to the permanent component as productivity changes because productivity shocks should have more complex dynamics. These dynamics may be exactly what is captured in the cross-shock relationships. 
and as late as July 2009 for Canada. Trough dates have not yet been selected for the U.S., U.K., or Italy. Given the importance of these recent events, we next explore the implications of this "Great Recession” based on our model. First, we estimated a model based on the data through 2007 to ensure that having the Great Recession at the end of the sample did not impact our estimates. We found that the estimates are remarkably robust comparing the sample through 2007 with the sample through 2009 . Next, we examined the estimated components for the 2005-2009 period. There appeared to be no particular pattern to the permanent components, but there is a striking similarity in the peak of the transitory components for the G-7 countries, as can be seen in Figure 2. Most countries, with the exception of the U.K. appeared to be at trend with a zero transitory component in the beginning of 2005. All seven countries experienced increases in their transitory components and appear to have a peaked in the first quarter of 2008 and crossed zero about the first quarter of 2009. Thus it appears that the common part of the 2007-2009 recession for the G-7 countries is captured in the transitory components.

\section{Conclusions}

In this paper we estimated a multivariate correlated unobserved components model for the G-7 countries from 1960 through 2009. Using this new methodology we are able to jointly address three major macroeconomic questions: 1) Are fluctuations in output primarily due to permanent or transitory movements? 2) Is the relative importance of permanent versus transitory movements in output similar across countries? 3) What is the pattern of correlation between the permanent and transitory movements in output across the G-7 countries? 
Our findings for the first and second questions suggest that fluctuations in output are primarily due to permanent movements for all of the G-7 countries. Once we allow for correlation between the countries, we find that the permanent component appears to account for a significant part of GDP fluctuations. We also find that the correlation between the permanent and transitory shocks within each country's GDP is significantly negative. These results are remarkably consistent across the G-7 countries. The results hold even after allowing for a structural break in the early 1970s for all countries and an additional structural break in the third quarter of 1991 for Japan. Finally, the model allows us to examine the correlations between permanent shocks and transitory shocks across countries for this period. We find that the correlation between permanent and transitory shocks across countries is important for modeling the real GDP of the G-7.

\section{References}

Ahmed, S., A. Levin and B. A. Wilson (2004). "Recent U.S. Macroeconomic Stability: Good Policies, Good Practices, or Good Luck?” The Review of Economics and Statistics, 86(3): 824-32.

Andrews, D. W. K. (1993). "Tests for Parameter Instability and Structural Change with Unknown Change Point." Econometrica 61(4): 821-856.

Asdrubali, P., B.E. Sørensen, and O. Yosha (1996). "Channels of interstate risk sharing: United States 1963-90.” Quarterly Journal of Economics 111(4): 1081-1110.

Backus, D. K., F. E. Kydland, and P. J. Kehoe (1992). "International Real Business Cycles.” Journal of Political Economy 100(4): 745-775.

Bai, J., R. L. Lumsdaine, and J. H. Stock (1998). "Testing for and Dating Common Breaks in Multivariate Time Series.” The Review of Economic Studies 65(3): 395-432.

Bai, J. and P. Perron (1998). "Estimating and Testing Linear Models with Multiple Structural Changes.” Econometrica 66(1): 47-78. 
Basistha, A. (2007). "Trend-Cycle Correlation, Drift Break and the Estimation of Trend and Cycle in Canadian GDP.” Canadian Journal of Economics 40(2): 584-606.

Baxter, M., and M.J Crucini (1995). "Business Cycles and the Asset Structure of Foreign trade.” International Economic Review 36(4): 821-853.

Becker, O. S. and M. Hoffman (2006). "Intra- and International Risk Sharing in the short run and the long run.” European Economic Review 50(3): 777-806.

Ben-David, D. and D. H. Papell (1998). "Slowdowns and Meltdowns: Post-War Growth Evidence from 74 Countries.” The Review of Economics and Statistics 80(4): 561-571.

Berger, Tino (forthcoming). “Estimating Europe’s Natural Rates” Empirical Economics.

Blanchard, O. J. and D. Quah (1989). “The Dynamic Effects of Aggregate Demand and Supply Disturbances.” The American Economic Review 79(4): 655-673.

Caballero, R.J. and Hammour, M.L. (1994). 'The Cleansing Effect of Recessions.' American Economic Review 84(5); 1075-1084.

Canova, F. and G. de Nicolo (2003). "On the Sources of Business Cycles in the G-7." Journal of International Economics 59(1): 77-100.

Centoni, M., G. Cubadda, and A. Hecq (2007). "Common Shocks, Common Dynamics, and the International Business Cycle.” Economic Modelling 24(2007): 149-166.

Chang, Y., Z. Miller, and J. Y. Park (2009). "Extracting Common Stochastic Trend: Theories with Some Applications,” Journal of Econometrics 150(2): 231-247.

Chauvet, Marcelle, and Chengxuan Yu (2006). "International Business Cycles: G7 and OECD Countries,” Federal Reserve Bank of Atlanta Economic Review. First Quarter: 4354.

Cogley, T. (1990). "International Evidence on the Size of the Random Walk in Output.” Journal of Political Economy 98(3): 501-518.

Cogley, T. and J. M. Nason (1995). "Effects of the Hodrick-Prescott Filter on Trend and Difference Stationary Time Series: Implications for Business Cycle Research.” Journal of Economic Dynamics and Control 19(1-2): 253-78.

Crucini, J.M., Kose, A. and Otrok, C (2008). "What are the driving forces of International Business Cycles?” NBER Working Papers, 14380, National Bureau of Economic Research, Inc.

Diebold, F. X. and G. D. Rudebusch (1996). "Measuring Business Cycles: A Modern Perspective.” The Review of Economics and Statistics, 78(1): 67-77. 
Doorn, D. (2006). “Consequences of Hodrick-Prescott Filtering for Parameter Estimation in a Structural Model of Inventory Behaviour.” Applied Economics 38(16): 1863-1875.

Doyle, B. M. and J. Faust (2002). “An Investigation of Co-movements among the Growth Rates of the G-7 Countries.” Federal Reserve Bulletin October 2002.

Doyle, B. M. and J. Faust (2005). "Breaks in the Variability and Comovement of G-7 Economic Growth.” The Review of Economics and Statistics 87(4): 721-740.

Everaert, G. (2007). "Estimating Long-Run Relationships between Observed Integrated Variables by Unobserved Components Methods.” SHERPPA, University of Ghent Working Paper.

Gregory, A., A. Head and J. Raynauld (1997). "Measuring World Business Cycles.” International Economic Review 38(3): 677-701.

Harding, D. and A. Pagan (2005). “A Suggested Framework for Classifying the Modes of Cycle Research.” Journal of Applied Econometrics 20(2): 151-159.

Hartley, P. R., and J. A. Whitt Jr (2003) "Macroeconomic Fluctuations: Demand or Supply, Permanent or Temporary?” European Economic Review 47: 61-94.

Harvey, A. C. (1993). Time Series Models. Cambridge, MA, MIT Press.

Kim, C.-J. and C. R. Nelson (1999a). State-Space Models with Regime Switching: Classical and Gibbs-Sampling Approaches with Applications. Cambridge, MA, MIT Press.

Kim, C.-J. and C. R. Nelson (1999b). "Has the U.S. Economy Become More Stable? A Bayesian Approach Based on a Markov-Switching Model of the Business Cycle." The Review of Economics and Statistics 81(4): 608-616.

Kim, C.-J., J. Piger and R. Startz (2007). "The Dynamic Relationship Between Permanent and Transitory Components of U.S. Business Cycles.” Journal of Money, Credit, and Banking 39(1): 187-204.

Kose, M. A., C. Otrok, and C. H. Whiteman (2003). "International Business Cycles: World, Region, and Country-Specific Factors.” American Economic Review 93(4): 12161239.

Kydland, F. E. and E. C. Prescott (1982). “Time to Build and Aggregate Fluctuations.” Econometrica 50(6): 1345-1370. 
Lippi, M. and L. Reichlin. (1994). "Diffusion of Technical Change and the Decomposition of Output into Trend and Cycle." The Review of Economic Studies, 61(1): 19-30.

McConnell, Margaret and Gabriel Perez-Quiros. (2000) "Output Fluctuations in the United States: What has changed since the early 1980s?" American Economic Review 90(5): 1464-76.

Mills, T. C. and P. Wang (2003). "Have Output Growth Rates Stabilised? Evidence from the G-7 Economies.” Scottish Journal of Political Economy 50(3): 232-246.

Ma, J. and M.E. Wohar (2009). "Real and Nominal Business Cycles: New Evidence from a Generalized Unobserved Components Model.” Working Paper.

Morley, J. C. (2007). "The Slow Adjustment of Aggregate Consumption to Permanent Income.” Journal of Money, Credit, and Banking 39(2-3): 615-638.

Morley, J. C., C. R. Nelson, and E. Zivot (2003). "Why Are the Beveridge-Nelson and Unobserved-Components Decompositions of GDP So Different?" The Review of Economics and Statistics 85(2): 235-243.

Murray, C. J. (2003). “Cyclical Properties of Baxter-King Filtered Time Series.” Review of Economics and Statistics 85(2): 472-76.

Nagakura, D. (2007). "Inference on the Correlation between Permanent and Transitory Shocks for Unidentified Unobserved Components Models.” SSRN Working Paper http://ssrn.com/abstract=981646.

Nagakura, D. (2008). "How Are Shocks to Trend and Cycle Correlated? A Simple Methodology for Unidentified Unobserved Components Models.” IMES Discussion Paper Series, 2008-E-24.

Papanyan, S. (2007). "The Dynamics of the Permanent and Transitory Components in International Business Cycles” SSRN Working Paper http://ssrn.com/abstract=794088.

Perron, P. and T. Wada (2006). "Let's Take a Break: Trends and Cycles in U.S. Real GDP.” Journal of Monetary Economics 56(6): 749- 765.

Prescott, E. C. (1987). "Theory Ahead of Business Cycle Measurement.” CarnegieRochester Conference on Public Policy 25:11-44.

Schleicher, C. (2003). "Structural Time Series Models with Common Trends and Common Cycles." Computing in Economics and Finance 2003-108, Society for Computational Economics. 
Sinclair, T. M. (2009). "The Relationships between Permanent and Transitory Movements in U.S. Output and the Unemployment Rate.” Journal of Money, Credit, and Banking 41(2-3): 529-542.

Sørensen, B. E. and O. Yosha (1998). “International risk sharing and European Monetary Unification.” Journal of International Economics 45(2): 211-238.

Stock, J. H. and M. W. Watson (1988). “Variable Trends in Economic Time Series.” Journal of Economic Perspectives 2(3): 147-174.

Stock, J. H. and M. W. Watson (2005). "Understanding Changes in International Business Cycle Dynamics.” Journal of the European Economic Association 3(5): 9661006.

Vahid, F. and R. F. Engle (1993). "Common Trends and Common Cycles.” Journal of Applied Econometrics 8(4): 341-360.

Vahid, F. and R. F. Engle (1997). “Codependent Cycles.” Journal of Econometrics 80(2): 199-221.

Van Dijk, Dick., Denise R. Osborn and Marianne Sensier. (2002) "Changes in Variability of the Business Cycle in the G7 Countries." Centre for Growth and Business Cycle Research Discussion Paper Series, University of Manchester, No. 16.

Wada, T. and Perron, P. (2006). "An Alternative Trend-Cycle Decomposition using a State Space Model with Mixtures of Normals: Specifications and Applications to International Data,” Working Paper, Boston University. 
Table 1: Drift Terms, AR Parameters, and Standard Deviations

Table 1a: Log Likelihood Values and Drift Terms

\begin{tabular}{|c|c|c|c|c|c|c|c|}
\hline & \multicolumn{3}{|c|}{$\begin{array}{c}\text { Model } 1 \\
\text { Unrestricted }\end{array}$} & \multicolumn{3}{|c|}{$\begin{array}{c}\text { Model } 2 \\
\text { No permanent- } \\
\text { transitory correlation } \\
\left(\Sigma_{\eta \varepsilon}=0\right)\end{array}$} & $\begin{array}{c}\text { Model } 3 \\
\text { No drift } \\
\text { breaks } \\
\left(\mu_{1}=\mu_{2}=\mu_{3}\right)\end{array}$ \\
\hline $\begin{array}{c}\text { Log } \\
\text { Likelihood } \\
\text { Value } \\
\end{array}$ & \multicolumn{3}{|c|}{-1599.81} & \multicolumn{3}{|c|}{-1690.99} & -1634.26 \\
\hline \multicolumn{8}{|c|}{ Drifts $\left(\mu_{i}\right)$ Estimate (SE) } \\
\hline $\begin{array}{c}\text { Canada } \\
\text { (break } \\
\text { 1974.2) }\end{array}$ & $\begin{array}{c}1.25 \\
(0.40)\end{array}$ & \multicolumn{2}{|c|}{$\begin{array}{c}0.66 \\
(0.14)\end{array}$} & $\begin{array}{c}1.36 \\
(0.09)\end{array}$ & \multicolumn{2}{|c|}{$\begin{array}{c}0.64 \\
(0.05)\end{array}$} & $\begin{array}{c}0.83 \\
(0.26)\end{array}$ \\
\hline $\begin{array}{c}\text { France } \\
\text { (break } \\
\text { 1974.2) } \\
\end{array}$ & $\begin{array}{c}1.72 \\
(0.20)\end{array}$ & \multicolumn{2}{|c|}{$\begin{array}{c}0.43 \\
(0.18)\end{array}$} & $\begin{array}{c}1.40 \\
(0.07)\end{array}$ & \multicolumn{2}{|c|}{$\begin{array}{c}0.49 \\
(0.04)\end{array}$} & $\begin{array}{c}0.75 \\
(0.57)\end{array}$ \\
\hline $\begin{array}{c}\text { Germany } \\
\text { (break } \\
\text { 1973.2) }\end{array}$ & $\begin{array}{c}1.04 \\
(0.24)\end{array}$ & \multicolumn{2}{|c|}{$\begin{array}{c}0.50 \\
(0.19)\end{array}$} & $\begin{array}{c}1.07 \\
(0.14)\end{array}$ & \multicolumn{2}{|c|}{$\begin{array}{c}0.46 \\
(0.08)\end{array}$} & $\begin{array}{c}0.62 \\
(0.49)\end{array}$ \\
\hline $\begin{array}{c}\text { Italy } \\
\text { (break } \\
\text { 1974.2) } \\
\end{array}$ & $\begin{array}{c}1.37 \\
(0.15)\end{array}$ & \multicolumn{2}{|c|}{$\begin{array}{c}0.41 \\
(0.15)\end{array}$} & $\begin{array}{c}1.40 \\
(0.12)\end{array}$ & \multicolumn{2}{|c|}{$\begin{array}{c}0.40 \\
(0.07)\end{array}$} & $\begin{array}{c}0.66 \\
(0.14)\end{array}$ \\
\hline $\begin{array}{c}\text { Japan } \\
\text { (breaks } \\
\text { 1973.2 \& } \\
\text { 1991.3) }\end{array}$ & $\begin{array}{c}2.58 \\
(0.30)\end{array}$ & $\begin{array}{c}0.76 \\
(0.49)\end{array}$ & $\begin{array}{c}0.24 \\
(0.37)\end{array}$ & $\begin{array}{c}2.30 \\
(0.11)\end{array}$ & $\begin{array}{c}0.84 \\
(0.07)\end{array}$ & $\begin{array}{c}0.33 \\
(0.06)\end{array}$ & $\begin{array}{c}0.75 \\
(1.12)\end{array}$ \\
\hline $\begin{array}{c}\text { U.K. } \\
\text { (break } \\
\text { 1973.2) } \\
\end{array}$ & $\begin{array}{c}1.36 \\
(0.89)\end{array}$ & \multicolumn{2}{|c|}{$\begin{array}{c}0.42 \\
(0.34)\end{array}$} & $\begin{array}{c}1.35 \\
(0.36)\end{array}$ & \multicolumn{2}{|c|}{$\begin{array}{c}0.58 \\
(0.08)\end{array}$} & $\begin{array}{c}0.59 \\
(0.11)\end{array}$ \\
\hline $\begin{array}{l}\text { U.S. } \\
\text { (break } \\
\text { 1973.2) }\end{array}$ & $\begin{array}{c}1.26 \\
(0.23)\end{array}$ & \multicolumn{2}{|c|}{$\begin{array}{c}0.66 \\
(0.12)\end{array}$} & $\begin{array}{c}1.16 \\
(0.12)\end{array}$ & \multicolumn{2}{|c|}{$\begin{array}{c}0.67 \\
(0.07)\end{array}$} & $\begin{array}{c}0.79 \\
(0.03)\end{array}$ \\
\hline
\end{tabular}


Table 1b: Autoregressive Parameters

\begin{tabular}{|c|c|c|c|}
\hline & $\begin{array}{c}\text { Model } 1 \\
\text { Unrestricted }\end{array}$ & $\begin{array}{c}\text { Model } 2 \\
\text { No permanent- } \\
\text { transitory correlation } \\
\left(\Sigma_{\eta \varepsilon}=0\right)\end{array}$ & $\begin{array}{c}\text { Model } 3 \\
\text { No drift breaks } \\
\left(\mu_{1}=\mu_{2}=\mu_{3}\right)\end{array}$ \\
\hline \multicolumn{4}{|c|}{$1^{\text {st }}$ AR parameter $\left(\phi_{1 i}\right)$ Estimate $(\mathrm{SE})$} \\
\hline Canada & $\begin{array}{c}1.36 \\
(0.11) \\
\end{array}$ & $\begin{array}{c}0.77 \\
(0.10) \\
\end{array}$ & $\begin{array}{c}0.81 \\
(0.03)\end{array}$ \\
\hline France & $\begin{array}{c}1.35 \\
(0.05) \\
\end{array}$ & $\begin{array}{c}0.40 \\
(0.08)\end{array}$ & $\begin{array}{c}1.30 \\
(0.08) \\
\end{array}$ \\
\hline Germany & $\begin{array}{c}1.35 \\
(0.01) \\
\end{array}$ & $\begin{array}{l}-0.38 \\
(0.01)\end{array}$ & $\begin{array}{c}1.28 \\
(0.04)\end{array}$ \\
\hline Italy & $\begin{array}{c}1.46 \\
(0.15) \\
\end{array}$ & $\begin{array}{c}0.00 \\
(0.01) \\
\end{array}$ & $\begin{array}{c}1.11 \\
(0.09) \\
\end{array}$ \\
\hline Japan & $\begin{array}{c}0.96 \\
(0.04)\end{array}$ & $\begin{array}{c}0.93 \\
(0.07)\end{array}$ & $\begin{array}{c}0.99 \\
(0.01)\end{array}$ \\
\hline U.K. & $\begin{array}{c}0.95 \\
(0.04) \\
\end{array}$ & $\begin{array}{c}0.91 \\
(0.07) \\
\end{array}$ & $\begin{array}{c}0.83 \\
(0.05) \\
\end{array}$ \\
\hline U.S. & $\begin{array}{c}1.38 \\
(0.11) \\
\end{array}$ & $\begin{array}{c}-0.41 \\
(0.17) \\
\end{array}$ & $\begin{array}{c}1.32 \\
(0.03) \\
\end{array}$ \\
\hline \multicolumn{4}{|c|}{$2^{\text {nd }}$ AR parameter $\left(\phi_{2 i}\right)$ Estimate $(\mathrm{SE})$} \\
\hline Canada & $\begin{array}{l}-0.45 \\
(0.13)\end{array}$ & $\begin{array}{l}-0.05 \\
(0.04)\end{array}$ & $\begin{array}{l}-0.06 \\
(0.03)\end{array}$ \\
\hline France & $\begin{array}{l}-0.49 \\
(0.07) \\
\end{array}$ & $\begin{array}{c}0.31 \\
(0.08) \\
\end{array}$ & $\begin{array}{l}-0.43 \\
(0.10) \\
\end{array}$ \\
\hline Germany & $\begin{array}{l}-0.54 \\
(0.04)\end{array}$ & $\begin{array}{l}-0.96 \\
(0.02)\end{array}$ & $\begin{array}{l}-0.50 \\
(0.06) \\
\end{array}$ \\
\hline Italy & $\begin{array}{l}-0.59 \\
(0.15)\end{array}$ & $\begin{array}{c}0.00 \\
(0.01)\end{array}$ & $\begin{array}{l}-0.26 \\
(0.11)\end{array}$ \\
\hline Japan & $\begin{array}{l}-0.06 \\
(0.04) \\
\end{array}$ & $\begin{array}{l}-0.04 \\
(0.05) \\
\end{array}$ & $\begin{array}{l}-0.03 \\
(0.02) \\
\end{array}$ \\
\hline U.K. & $\begin{array}{l}-0.04 \\
(0.06)\end{array}$ & $\begin{array}{c}0.07 \\
(0.07)\end{array}$ & $\begin{array}{c}0.03 \\
(0.03)\end{array}$ \\
\hline U.S. & $\begin{array}{c}-0.55 \\
(0.11) \\
\end{array}$ & $\begin{array}{c}0.45 \\
(0.16) \\
\end{array}$ & $\begin{array}{l}-0.72 \\
(0.01)\end{array}$ \\
\hline
\end{tabular}


Table 1c: Standard Deviations

\begin{tabular}{|c|c|c|c|c|c|}
\hline \multirow[b]{2}{*}{ Country } & \multirow[b]{2}{*}{$\begin{array}{c}\text { Standard } \\
\text { Deviations of the } \\
\text { Real GDP Growth } \\
\text { Rate }^{13}\end{array}$} & \multicolumn{4}{|c|}{ Standard Deviation Estimate (SE) } \\
\hline & & Shock Type & $\begin{array}{c}\text { Model } 1 \\
\text { Unrestricted }\end{array}$ & $\begin{array}{c}\text { Model } 2 \\
\text { No } \\
\text { permanent- } \\
\text { transitory } \\
\text { correlation } \\
\left(\Sigma_{\eta \varepsilon}=0\right)\end{array}$ & $\begin{array}{c}\text { Model } 3 \\
\text { No drift } \\
\text { breaks } \\
\left(\mu_{1}=\mu_{2}=\mu_{3}\right)\end{array}$ \\
\hline \multirow{2}{*}{ Canada } & \multirow{2}{*}{0.90} & $\begin{array}{c}\text { Permanent Shocks } \\
\left(\sigma_{\eta i}\right)\end{array}$ & $\begin{array}{c}1.71 \\
(0.45)\end{array}$ & $\begin{array}{c}0.64 \\
(0.06)\end{array}$ & $\begin{array}{c}1.34 \\
(0.14)\end{array}$ \\
\hline & & $\begin{array}{c}\text { Transitory Shocks } \\
\left(\sigma_{\varepsilon i}\right) \\
\end{array}$ & $\begin{array}{c}1.51 \\
(0.42) \\
\end{array}$ & $\begin{array}{c}0.51 \\
(0.06) \\
\end{array}$ & $\begin{array}{c}1.47 \\
(0.24) \\
\end{array}$ \\
\hline \multirow{2}{*}{ France } & \multirow{2}{*}{0.99} & $\begin{array}{c}\text { Permanent Shocks } \\
\left(\sigma_{\eta i}\right)\end{array}$ & $\begin{array}{c}1.56 \\
(0.29)\end{array}$ & $\begin{array}{c}0.51 \\
(0.04)\end{array}$ & $\begin{array}{c}1.86 \\
(0.34)\end{array}$ \\
\hline & & $\begin{array}{c}\text { Transitory Shocks } \\
\left(\sigma_{\varepsilon i}\right)\end{array}$ & $\begin{array}{c}0.93 \\
(0.38)\end{array}$ & $\begin{array}{c}0.64 \\
(0.05)\end{array}$ & $\begin{array}{c}1.25 \\
(0.44)\end{array}$ \\
\hline \multirow{2}{*}{ Germany } & \multirow{2}{*}{1.13} & $\begin{array}{c}\text { Permanent Shocks } \\
\left(\sigma_{\eta i}\right)\end{array}$ & $\begin{array}{c}1.67 \\
(0.22) \\
\end{array}$ & $\begin{array}{c}1.03 \\
(0.05) \\
\end{array}$ & $\begin{array}{c}1.78 \\
(0.20) \\
\end{array}$ \\
\hline & & $\begin{array}{c}\text { Transitory Shocks } \\
\left(\sigma_{\varepsilon i}\right)\end{array}$ & $\begin{array}{c}0.80 \\
(0.29) \\
\end{array}$ & $\begin{array}{c}0.04 \\
(0.02) \\
\end{array}$ & $\begin{array}{c}0.84 \\
(0.14) \\
\end{array}$ \\
\hline \multirow{2}{*}{ Italy } & \multirow{2}{*}{1.02} & $\begin{array}{c}\text { Permanent Shocks } \\
\left(\sigma_{\eta i}\right)\end{array}$ & $\begin{array}{c}1.17 \\
(0.01) \\
\end{array}$ & $\begin{array}{c}0.88 \\
(0.05) \\
\end{array}$ & $\begin{array}{c}1.55 \\
(0.13) \\
\end{array}$ \\
\hline & & $\begin{array}{c}\text { Transitory Shocks } \\
\left(\sigma_{\varepsilon i}\right)\end{array}$ & $\begin{array}{c}0.88 \\
(0.14) \\
\end{array}$ & $\begin{array}{c}0.21 \\
(0.05) \\
\end{array}$ & $\begin{array}{c}1.67 \\
(0.16) \\
\end{array}$ \\
\hline \multirow{2}{*}{ Japan } & \multirow{2}{*}{1.30} & $\begin{array}{c}\text { Permanent Shocks } \\
\left(\sigma_{\eta i}\right)\end{array}$ & $\begin{array}{c}2.61 \\
(0.31)\end{array}$ & $\begin{array}{c}0.61 \\
(0.12)\end{array}$ & $\begin{array}{c}4.92 \\
(0.93)\end{array}$ \\
\hline & & $\begin{array}{c}\text { Transitory Shocks } \\
\left(\sigma_{\varepsilon i}\right)\end{array}$ & $\begin{array}{c}2.74 \\
(0.24) \\
\end{array}$ & $\begin{array}{c}0.79 \\
(0.07) \\
\end{array}$ & $\begin{array}{c}5.06 \\
(0.74) \\
\end{array}$ \\
\hline \multirow{2}{*}{ U.K. } & \multirow{2}{*}{0.98} & $\begin{array}{c}\text { Permanent Shocks } \\
\left(\sigma_{\eta i}\right) \\
\end{array}$ & $\begin{array}{c}2.02 \\
(0.20) \\
\end{array}$ & $\begin{array}{c}0.57 \\
(0.09) \\
\end{array}$ & $\begin{array}{c}1.59 \\
(0.29) \\
\end{array}$ \\
\hline & & $\begin{array}{c}\text { Transitory Shocks } \\
\left(\sigma_{\varepsilon i}\right)\end{array}$ & $\begin{array}{c}2.17 \\
(0.53)\end{array}$ & $\begin{array}{c}0.77 \\
(0.05)\end{array}$ & $\begin{array}{c}1.48 \\
(0.10)\end{array}$ \\
\hline \multirow{2}{*}{ U.S. } & \multirow{2}{*}{0.87} & $\begin{array}{c}\text { Permanent Shocks } \\
\left(\sigma_{\eta i}\right) \\
\end{array}$ & $\begin{array}{c}1.00 \\
(0.19) \\
\end{array}$ & $\begin{array}{c}0.81 \\
(0.04) \\
\end{array}$ & $\begin{array}{c}1.03 \\
(0.17) \\
\end{array}$ \\
\hline & & $\begin{array}{c}\text { Transitory Shocks } \\
\left(\sigma_{\varepsilon i}\right)\end{array}$ & $\begin{array}{c}0.83 \\
(0.17) \\
\end{array}$ & $\begin{array}{c}0.07 \\
(0.02) \\
\end{array}$ & $\begin{array}{c}0.41 \\
(0.09) \\
\end{array}$ \\
\hline
\end{tabular}

\footnotetext{
${ }^{13}$ The growth rate of real GDP is defined as the difference in the natural log of real GDP times 100 for each country. These standard deviations are calculated for the raw series and do not incorporate structural breaks.
} 
Table 1d: Correlations between Within-Series Permanent and Transitory Shocks

\begin{tabular}{|c|c|c|c|}
\hline & $\begin{array}{c}\text { Model 1 } \\
\text { Unrestricted }\end{array}$ & $\begin{array}{c}\text { Model 2 } \\
\text { No permanent- } \\
\text { transitory } \\
\text { correlation } \\
\left(\boldsymbol{\Sigma}_{\boldsymbol{\eta}}=\mathbf{0}\right)\end{array}$ & $\begin{array}{c}\text { Model 3 } \\
\text { No drift breaks } \\
\left(\boldsymbol{\mu}_{\mathbf{1}}=\boldsymbol{\mu}_{\mathbf{2}}=\boldsymbol{\mu}_{\mathbf{3}}\right)\end{array}$ \\
\hline \multicolumn{3}{|c|}{ Correlation between the Permanent Innovation } \\
and Transitory Innovation for the Same Series $\left(\boldsymbol{\rho}_{\eta i \varepsilon i}\right)$ Estimate (SE)
\end{tabular}


Table 1e: Correlation Parameters, Permanent Shocks $\left(\Sigma_{\eta}\right)$

\begin{tabular}{|c|c|c|c|c|}
\hline & & $\begin{array}{c}\text { Model } 1 \\
\text { Unrestricted }\end{array}$ & $\begin{array}{c}\text { Model } 2 \\
\text { No permanent- } \\
\text { transitory } \\
\text { correlation } \\
\left(\Sigma_{\eta \varepsilon}=\mathbf{0}\right)\end{array}$ & $\begin{array}{c}\text { Model } 3 \\
\text { No drift breaks } \\
\left(\mu_{1}=\mu_{2}=\mu_{3}\right)\end{array}$ \\
\hline$\underset{i}{\text { Country }}$ & $\underset{j}{\text { Country }}$ & \multicolumn{3}{|c|}{$\begin{array}{l}\text { Pairwise Correlation between } \\
\text { the Permanent Shocks }\left(\rho_{\eta i \eta j}\right) \text { Estimate (SE) }\end{array}$} \\
\hline Canada & France & $\begin{array}{l}-0.09 \\
(0.10)\end{array}$ & $\begin{array}{c}0.65 \\
(0.07)\end{array}$ & $\begin{array}{c}0.44 \\
(0.14)\end{array}$ \\
\hline Canada & Germany & $\begin{array}{c}0.04 \\
(0.02)\end{array}$ & $\begin{array}{c}0.20 \\
(0.06)\end{array}$ & $\begin{array}{c}0.30 \\
(0.06)\end{array}$ \\
\hline Canada & Italy & $\begin{array}{l}-0.01 \\
(0.00)\end{array}$ & $\begin{array}{c}0.38 \\
(0.09) \\
\end{array}$ & $\begin{array}{c}0.65 \\
(0.09) \\
\end{array}$ \\
\hline Canada & Japan & $\begin{array}{l}-0.55 \\
(0.16)\end{array}$ & $\begin{array}{c}0.05 \\
(0.04)\end{array}$ & $\begin{array}{c}0.24 \\
(0.16)\end{array}$ \\
\hline Canada & UK & $\begin{array}{c}0.63 \\
(0.71)\end{array}$ & $\begin{array}{c}0.91 \\
(0.06)\end{array}$ & $\begin{array}{c}0.54 \\
(0.11)\end{array}$ \\
\hline Canada & US & $\begin{array}{c}0.41 \\
(0.12)\end{array}$ & $\begin{array}{c}0.66 \\
(0.06)\end{array}$ & $\begin{array}{c}0.74 \\
(0.25)\end{array}$ \\
\hline France & Germany & $\begin{array}{c}0.45 \\
(0.10)\end{array}$ & $\begin{array}{c}0.76 \\
(0.07)\end{array}$ & $\begin{array}{c}0.54 \\
(0.18)\end{array}$ \\
\hline France & Italy & $\begin{array}{c}0.36 \\
(0.07)\end{array}$ & $\begin{array}{c}0.61 \\
(0.08)\end{array}$ & $\begin{array}{c}0.42 \\
(0.18)\end{array}$ \\
\hline France & Japan & $\begin{array}{c}0.20 \\
(0.09)\end{array}$ & $\begin{array}{c}0.24 \\
(0.08)\end{array}$ & $\begin{array}{l}-0.09 \\
(0.29)\end{array}$ \\
\hline France & UK & $\begin{array}{c}0.40 \\
(0.50)\end{array}$ & $\begin{array}{c}0.88 \\
(0.06)\end{array}$ & $\begin{array}{c}0.27 \\
(0.16)\end{array}$ \\
\hline France & US & $\begin{array}{c}0.32 \\
(0.05)\end{array}$ & $\begin{array}{c}0.21 \\
(0.10)\end{array}$ & $\begin{array}{c}0.30 \\
(0.24)\end{array}$ \\
\hline Germany & Italy & $\begin{array}{c}0.14 \\
(0.05)\end{array}$ & $\begin{array}{c}0.31 \\
(0.07)\end{array}$ & $\begin{array}{c}0.15 \\
(0.11)\end{array}$ \\
\hline Germany & Japan & $\begin{array}{l}-0.34 \\
(0.27)\end{array}$ & $\begin{array}{c}0.32 \\
(0.09)\end{array}$ & $\begin{array}{c}-0.19 \\
(0.19)\end{array}$ \\
\hline Germany & UK & $\begin{array}{l}-0.03 \\
(0.51)\end{array}$ & $\begin{array}{c}0.58 \\
(0.13)\end{array}$ & $\begin{array}{c}-0.22 \\
(0.06)\end{array}$ \\
\hline Germany & US & $\begin{array}{c}0.06 \\
(0.15)\end{array}$ & $\begin{array}{c}0.21 \\
(0.07)\end{array}$ & $\begin{array}{c}0.24 \\
(0.13)\end{array}$ \\
\hline Italy & Japan & $\begin{array}{c}0.70 \\
(0.07)\end{array}$ & $\begin{array}{c}0.80 \\
(0.08)\end{array}$ & $\begin{array}{c}0.63 \\
(0.07)\end{array}$ \\
\hline Italy & UK & $\begin{array}{c}0.18 \\
(0.22)\end{array}$ & $\begin{array}{c}0.44 \\
(0.13)\end{array}$ & $\begin{array}{c}0.22 \\
(0.20)\end{array}$ \\
\hline Italy & US & $\begin{array}{c}0.33 \\
(0.17)\end{array}$ & $\begin{array}{c}0.16 \\
(0.07)\end{array}$ & $\begin{array}{c}0.53 \\
(0.12)\end{array}$ \\
\hline Japan & UK & $\begin{array}{l}-0.07 \\
(0.36)\end{array}$ & $\begin{array}{c}0.13 \\
(0.10)\end{array}$ & $\begin{array}{c}0.21 \\
(0.18)\end{array}$ \\
\hline Japan & US & $\begin{array}{c}0.07 \\
(0.12)\end{array}$ & $\begin{array}{c}0.36 \\
(0.09)\end{array}$ & $\begin{array}{c}0.56 \\
(0.04)\end{array}$ \\
\hline UK & US & $\begin{array}{c}0.52 \\
(0.38)\end{array}$ & $\begin{array}{c}0.57 \\
(0.07)\end{array}$ & $\begin{array}{c}0.74 \\
(0.02)\end{array}$ \\
\hline
\end{tabular}


Table 1f: Correlation Parameters, Transitory Shocks $\left(\Sigma_{\varepsilon}\right)$

\begin{tabular}{|c|c|c|c|c|}
\hline & & $\begin{array}{c}\text { Model } 1 \\
\text { Unrestricted }\end{array}$ & $\begin{array}{c}\text { Model } 2 \\
\text { No permanent- } \\
\text { transitory } \\
\text { correlation } \\
\left(\Sigma_{\eta \varepsilon}=0\right) \\
\end{array}$ & $\begin{array}{c}\text { Model } 3 \\
\text { No drift breaks } \\
\left(\mu_{1}=\mu_{2}=\mu_{3}\right)\end{array}$ \\
\hline$\underset{i}{\text { Country }}$ & $\underset{j}{\text { Country }}$ & \multicolumn{3}{|c|}{$\begin{array}{c}\text { Pairwise Correlation between the } \\
\text { Transitory Shocks }\left(\rho_{\varepsilon i \varepsilon j}\right) \text { Estimate (SE) }\end{array}$} \\
\hline Canada & France & $\begin{array}{c}0.04 \\
(0.05)\end{array}$ & $\begin{array}{l}-0.42 \\
(0.12)\end{array}$ & $\begin{array}{c}0.48 \\
(0.07)\end{array}$ \\
\hline Canada & Germany & $\begin{array}{c}0.32 \\
(0.06) \\
\end{array}$ & $\begin{array}{c}0.36 \\
(0.21) \\
\end{array}$ & $\begin{array}{c}0.38 \\
(0.09) \\
\end{array}$ \\
\hline Canada & Italy & $\begin{array}{c}0.32 \\
(0.16)\end{array}$ & $\begin{array}{l}-0.69 \\
(0.24)\end{array}$ & $\begin{array}{c}0.77 \\
(0.09)\end{array}$ \\
\hline Canada & Japan & $\begin{array}{l}-0.33 \\
(0.14)\end{array}$ & $\begin{array}{c}0.26 \\
(0.15)\end{array}$ & $\begin{array}{l}0.41 \\
(0.11)\end{array}$ \\
\hline Canada & UK & $\begin{array}{c}0.67 \\
(0.35)\end{array}$ & $\begin{array}{l}-0.30 \\
(0.12)\end{array}$ & $\begin{array}{c}0.21 \\
(0.11)\end{array}$ \\
\hline Canada & US & $\begin{array}{c}0.79 \\
(0.07)\end{array}$ & $\begin{array}{c}0.18 \\
(0.35) \\
\end{array}$ & $\begin{array}{c}0.71 \\
(0.21)\end{array}$ \\
\hline France & Germany & $\begin{array}{c}0.68 \\
(0.07)\end{array}$ & $\begin{array}{l}-0.41 \\
(0.19)\end{array}$ & $\begin{array}{c}0.75 \\
(0.12)\end{array}$ \\
\hline France & Italy & $\begin{array}{c}0.69 \\
(0.04) \\
\end{array}$ & $\begin{array}{l}-0.04 \\
(0.35)\end{array}$ & $\begin{array}{c}0.61 \\
(0.04)\end{array}$ \\
\hline France & Japan & $\begin{array}{c}0.27 \\
(0.04)\end{array}$ & $\begin{array}{c}0.17 \\
(0.09)\end{array}$ & $\begin{array}{c}0.05 \\
(0.21)\end{array}$ \\
\hline France & UK & $\begin{array}{c}0.41 \\
(0.40)\end{array}$ & $\begin{array}{c}0.12 \\
(0.07)\end{array}$ & $\begin{array}{c}0.04 \\
(0.01)\end{array}$ \\
\hline France & US & $\begin{array}{c}0.54 \\
(0.06) \\
\end{array}$ & $\begin{array}{c}0.36 \\
(0.30) \\
\end{array}$ & $\begin{array}{c}0.58 \\
(0.13) \\
\end{array}$ \\
\hline Germany & Italy & $\begin{array}{c}0.50 \\
(0.09)\end{array}$ & $\begin{array}{l}-0.69 \\
(0.49)\end{array}$ & $\begin{array}{c}0.47 \\
(0.01)\end{array}$ \\
\hline Germany & Japan & $\begin{array}{l}-0.18 \\
(0.28) \\
\end{array}$ & $\begin{array}{c}0.41 \\
(0.31) \\
\end{array}$ & $\begin{array}{c}0.05 \\
(0.18) \\
\end{array}$ \\
\hline Germany & UK & $\begin{array}{c}0.24 \\
(0.38)\end{array}$ & $\begin{array}{c}0.74 \\
(0.14)\end{array}$ & $\begin{array}{l}-0.34 \\
(0.04)\end{array}$ \\
\hline Germany & US & $\begin{array}{c}0.50 \\
(0.16) \\
\end{array}$ & $\begin{array}{l}-0.83 \\
(0.14) \\
\end{array}$ & $\begin{array}{c}0.50 \\
(0.04)\end{array}$ \\
\hline Italy & Japan & $\begin{array}{c}0.57 \\
(0.09)\end{array}$ & $\begin{array}{l}-0.59 \\
(0.20)\end{array}$ & $\begin{array}{c}0.67 \\
(0.06)\end{array}$ \\
\hline Italy & UK & $\begin{array}{c}0.52 \\
(0.49)\end{array}$ & $\begin{array}{l}-0.37 \\
(0.27)\end{array}$ & $\begin{array}{c}0.28 \\
(0.07)\end{array}$ \\
\hline Italy & US & $\begin{array}{c}0.71 \\
(0.17)\end{array}$ & $\begin{array}{c}0.21 \\
(0.64)\end{array}$ & $\begin{array}{c}0.75 \\
(0.09)\end{array}$ \\
\hline Japan & UK & $\begin{array}{c}0.24 \\
(0.30)\end{array}$ & $\begin{array}{c}0.33 \\
(0.12)\end{array}$ & $\begin{array}{c}0.59 \\
(0.08)\end{array}$ \\
\hline Japan & US & $\begin{array}{c}0.07 \\
(0.21)\end{array}$ & $\begin{array}{c}-0.27 \\
(0.17)\end{array}$ & $\begin{array}{c}0.66 \\
(0.08)\end{array}$ \\
\hline UK & US & $\begin{array}{c}0.88 \\
(0.13)\end{array}$ & $\begin{array}{l}-0.86 \\
(0.15)\end{array}$ & $\begin{array}{c}0.58 \\
(0.03)\end{array}$ \\
\hline
\end{tabular}


Table 1g: Correlation Parameters, Cross-Country Permanent/Transitory Shocks $\left(\Sigma_{\eta \varepsilon}\right)$

\begin{tabular}{|c|c|c|c|c|}
\hline & & $\begin{array}{c}\text { Model } 1 \\
\text { Unrestricted }\end{array}$ & $\begin{array}{c}\text { Model } 2 \\
\text { No permanent- } \\
\text { transitory } \\
\text { correlation } \\
\left(\Sigma_{\eta \varepsilon}=0\right) \\
\end{array}$ & $\begin{array}{c}\text { Model } 3 \\
\text { No drift breaks } \\
\left(\mu_{1}=\mu_{2}=\mu_{3}\right)\end{array}$ \\
\hline $\begin{array}{c}\text { Country } \\
i\end{array}$ & $\begin{array}{c}\text { Country } \\
j\end{array}$ & \multicolumn{3}{|c|}{$\begin{array}{l}\text { Pairwise Correlation between the Cross-Country } \\
\text { Permanent/Transitory Shocks }\left(\rho_{\eta i \varepsilon j}\right) \text { Estimate } \\
\text { (SE) }\end{array}$} \\
\hline Canada & France & $\begin{array}{c}0.07 \\
(0.09)\end{array}$ & $\begin{array}{c}0 \\
\text { (by assumption) }\end{array}$ & $\begin{array}{c}-0.44 \\
(0.13)\end{array}$ \\
\hline Canada & Germany & $\begin{array}{l}-0.22 \\
(0.04)\end{array}$ & $\begin{array}{c}0 \\
\text { (by assumption) }\end{array}$ & $\begin{array}{l}-0.34 \\
(0.07)\end{array}$ \\
\hline Canada & Italy & $\begin{array}{l}-0.19 \\
(0.17)\end{array}$ & $\begin{array}{c}0 \\
\text { (by assumption) }\end{array}$ & $\begin{array}{l}-0.55 \\
(0.09)\end{array}$ \\
\hline Canada & Japan & $\begin{array}{c}0.43 \\
(0.13) \\
\end{array}$ & $\begin{array}{c}0 \\
\text { (by assumption) }\end{array}$ & $\begin{array}{l}-0.31 \\
(0.13) \\
\end{array}$ \\
\hline Canada & UK & $\begin{array}{l}-0.60 \\
(0.45)\end{array}$ & $\begin{array}{c}0 \\
\text { (by assumption) }\end{array}$ & $\begin{array}{l}-0.38 \\
(0.13)\end{array}$ \\
\hline Canada & US & $\begin{array}{l}-0.72 \\
(0.07)\end{array}$ & $\begin{array}{c}0 \\
\text { (by assumption) }\end{array}$ & $\begin{array}{l}-0.74 \\
(0.20)\end{array}$ \\
\hline France & Canada & $\begin{array}{c}0.00 \\
(0.03)\end{array}$ & $\begin{array}{c}0 \\
\text { (by assumption) }\end{array}$ & $\begin{array}{l}-0.45 \\
(0.09)\end{array}$ \\
\hline France & Germany & $\begin{array}{l}-0.51 \\
(0.07)\end{array}$ & $\begin{array}{c}0 \\
\text { (by assumption) }\end{array}$ & $\begin{array}{l}-0.59 \\
(0.06)\end{array}$ \\
\hline France & Italy & $\begin{array}{l}-0.56 \\
(0.15)\end{array}$ & $\begin{array}{c}0 \\
\text { (by assumption) }\end{array}$ & $\begin{array}{l}-0.47 \\
(0.09)\end{array}$ \\
\hline France & Japan & $\begin{array}{l}-0.22 \\
(0.12)\end{array}$ & $\begin{array}{c}0 \\
\text { (by assumption) }\end{array}$ & $\begin{array}{c}0.08 \\
(0.26)\end{array}$ \\
\hline France & UK & $\begin{array}{l}-0.33 \\
(0.45)\end{array}$ & $\begin{array}{c}0 \\
\text { (by assumption) }\end{array}$ & $\begin{array}{l}-0.12 \\
(0.07)\end{array}$ \\
\hline France & US & $\begin{array}{l}-0.43 \\
(0.11)\end{array}$ & $\begin{array}{c}0 \\
\text { (by assumption) }\end{array}$ & $\begin{array}{l}-0.52 \\
(0.22)\end{array}$ \\
\hline Germany & Canada & $\begin{array}{l}-0.11 \\
(0.04)\end{array}$ & $\begin{array}{c}0 \\
\text { (by assumption) }\end{array}$ & $\begin{array}{l}-0.27 \\
(0.06)\end{array}$ \\
\hline Germany & France & $\begin{array}{l}-0.54 \\
(0.18)\end{array}$ & $\begin{array}{c}0 \\
\text { (by assumption) }\end{array}$ & $\begin{array}{l}-0.65 \\
(0.24)\end{array}$ \\
\hline Germany & Italy & $\begin{array}{l}-0.27 \\
(0.15)\end{array}$ & $\begin{array}{c}0 \\
\text { (by assumption) }\end{array}$ & $\begin{array}{l}-0.21 \\
(0.13)\end{array}$ \\
\hline Germany & Japan & $\begin{array}{c}0.30 \\
(0.39) \\
\end{array}$ & $\begin{array}{c}0 \\
\text { (by assumption) }\end{array}$ & $\begin{array}{c}0.20 \\
(0.19)\end{array}$ \\
\hline Germany & UK & $\begin{array}{c}0.11 \\
(0.52)\end{array}$ & $\begin{array}{c}0 \\
\text { (by assumption) }\end{array}$ & $\begin{array}{c}0.42 \\
(0.09)\end{array}$ \\
\hline Germany & US & $\begin{array}{l}-0.17 \\
(0.29)\end{array}$ & $\begin{array}{c}0 \\
\text { (by assumption) }\end{array}$ & $\begin{array}{l}-0.37 \\
(0.13)\end{array}$ \\
\hline
\end{tabular}


Table 1g (cont.): Corr. Parameters, Cross-Country Perm./Trans. Shocks $\left(\Sigma_{\eta \varepsilon}\right)$

\begin{tabular}{|c|c|c|c|c|}
\hline & & $\begin{array}{c}\text { Model } 1 \\
\text { Unrestricted }\end{array}$ & $\begin{array}{c}\text { Model } 2 \\
\text { No perm-trans } \\
\text { correlation } \\
\left(\Sigma_{\eta \varepsilon}=\mathbf{0}\right) \\
\end{array}$ & $\begin{array}{c}\text { Model } 3 \\
\text { No drift breaks } \\
\left(\mu_{1}=\mu_{2}=\mu_{3}\right)\end{array}$ \\
\hline Country $i$ & Country $j$ & \multicolumn{3}{|c|}{$\left(\rho_{\eta i \varepsilon j}\right)$ Estimate (SE) } \\
\hline Italy & Canada & $\begin{array}{c}-0.11 \\
(0.05)\end{array}$ & $\begin{array}{c}0 \\
\text { (by assumption) }\end{array}$ & $\begin{array}{l}-0.89 \\
(0.02)\end{array}$ \\
\hline Italy & France & $\begin{array}{l}-0.44 \\
(0.08)\end{array}$ & $\begin{array}{c}0 \\
\text { (by assumption) }\end{array}$ & $\begin{array}{l}-0.47 \\
(0.11)\end{array}$ \\
\hline Italy & Germany & $\begin{array}{l}-0.26 \\
(0.04)\end{array}$ & $\begin{array}{c}0 \\
\text { (by assumption) }\end{array}$ & $\begin{array}{l}-0.33 \\
(0.04)\end{array}$ \\
\hline Italy & Japan & $\begin{array}{l}-0.67 \\
(0.07)\end{array}$ & $\begin{array}{c}0 \\
\text { (by assumption) }\end{array}$ & $\begin{array}{l}-0.64 \\
(0.08)\end{array}$ \\
\hline Italy & UK & $\begin{array}{l}-0.21 \\
(0.18)\end{array}$ & $\begin{array}{c}0 \\
\text { (by assumption) }\end{array}$ & $\begin{array}{l}-0.30 \\
(0.07)\end{array}$ \\
\hline Italy & US & $\begin{array}{l}-0.36 \\
(0.04)\end{array}$ & $\begin{array}{c}0 \\
\text { (by assumption) }\end{array}$ & $\begin{array}{l}-0.77 \\
(0.10)\end{array}$ \\
\hline Japan & Canada & $\begin{array}{c}0.48 \\
(0.18) \\
\end{array}$ & $\begin{array}{c}0 \\
\text { (by assumption) }\end{array}$ & $\begin{array}{l}-0.36 \\
(0.13)\end{array}$ \\
\hline Japan & France & $\begin{array}{l}-0.21 \\
(0.05)\end{array}$ & $\begin{array}{c}0 \\
\text { (by assumption) }\end{array}$ & $\begin{array}{l}-0.03 \\
(0.23)\end{array}$ \\
\hline Japan & Germany & $\begin{array}{c}0.29 \\
(0.15)\end{array}$ & $\begin{array}{c}0 \\
\text { (by assumption) }\end{array}$ & $\begin{array}{l}-0.04 \\
(0.19)\end{array}$ \\
\hline Japan & Italy & $\begin{array}{l}-0.47 \\
(0.16)\end{array}$ & $\begin{array}{c}0 \\
\text { (by assumption) }\end{array}$ & $\begin{array}{l}-0.64 \\
(0.07)\end{array}$ \\
\hline Japan & UK & $\begin{array}{c}0.01 \\
(0.16)\end{array}$ & $\begin{array}{c}0 \\
\text { (by assumption) }\end{array}$ & $\begin{array}{l}-0.61 \\
(0.10)\end{array}$ \\
\hline Japan & US & $\begin{array}{c}0.12 \\
(0.25)\end{array}$ & $\begin{array}{c}0 \\
\text { (by assumption) }\end{array}$ & $\begin{array}{l}-0.68 \\
(0.04)\end{array}$ \\
\hline UK & Canada & $\begin{array}{l}-0.70 \\
(0.58)\end{array}$ & $\begin{array}{c}0 \\
\text { (by assumption) }\end{array}$ & $\begin{array}{l}-0.33 \\
(0.17)\end{array}$ \\
\hline UK & France & $\begin{array}{l}-0.38 \\
(0.47)\end{array}$ & $\begin{array}{c}0 \\
\text { (by assumption) }\end{array}$ & $\begin{array}{l}-0.14 \\
(0.10)\end{array}$ \\
\hline UK & Germany & $\begin{array}{l}-0.20 \\
(0.38)\end{array}$ & $\begin{array}{c}0 \\
\text { (by assumption) }\end{array}$ & $\begin{array}{c}0.25 \\
(0.06)\end{array}$ \\
\hline UK & Italy & $\begin{array}{l}-0.48 \\
(0.56)\end{array}$ & $\begin{array}{c}0 \\
\text { (by assumption) }\end{array}$ & $\begin{array}{l}-0.20 \\
(0.23)\end{array}$ \\
\hline UK & Japan & $\begin{array}{l}-0.17 \\
(0.48)\end{array}$ & $\begin{array}{c}0 \\
\text { (by assumption) }\end{array}$ & $\begin{array}{l}-0.17 \\
(0.16)\end{array}$ \\
\hline UK & US & $\begin{array}{l}-0.81 \\
(0.22)\end{array}$ & $\begin{array}{c}0 \\
\text { (by assumption) }\end{array}$ & $\begin{array}{l}-0.51 \\
(0.25)\end{array}$ \\
\hline US & Canada & $\begin{array}{l}-0.47 \\
(0.12)\end{array}$ & $\begin{array}{c}0 \\
\text { (by assumption) }\end{array}$ & $\begin{array}{l}-0.59 \\
(0.26)\end{array}$ \\
\hline US & France & $\begin{array}{l}-0.45 \\
(0.15) \\
\end{array}$ & $\begin{array}{c}0 \\
\text { (by assumption) }\end{array}$ & $\begin{array}{l}-0.32 \\
(0.21)\end{array}$ \\
\hline US & Germany & $\begin{array}{l}-0.32 \\
(0.19)\end{array}$ & $\begin{array}{c}0 \\
\text { (by assumption) }\end{array}$ & $\begin{array}{l}-0.28 \\
(0.04)\end{array}$ \\
\hline US & Italy & $\begin{array}{l}-0.74 \\
(0.05)\end{array}$ & $\begin{array}{c}0 \\
\text { (by assumption) } \\
\end{array}$ & $\begin{array}{l}-0.52 \\
(0.16)\end{array}$ \\
\hline US & Japan & $\begin{array}{l}-0.19 \\
(0.08)\end{array}$ & $\begin{array}{c}0 \\
\text { (by assumption) }\end{array}$ & $\begin{array}{l}-0.52 \\
(0.05)\end{array}$ \\
\hline US & UK & $\begin{array}{l}-0.57 \\
(0.32)\end{array}$ & $\begin{array}{c}0 \\
\text { (by assumption) }\end{array}$ & $\begin{array}{l}-0.68 \\
(0.05)\end{array}$ \\
\hline
\end{tabular}


Figure 1: Real GDP and the Estimated Components ${ }^{14}$

\section{$\underline{\text { Panel 1: Canada }}$}

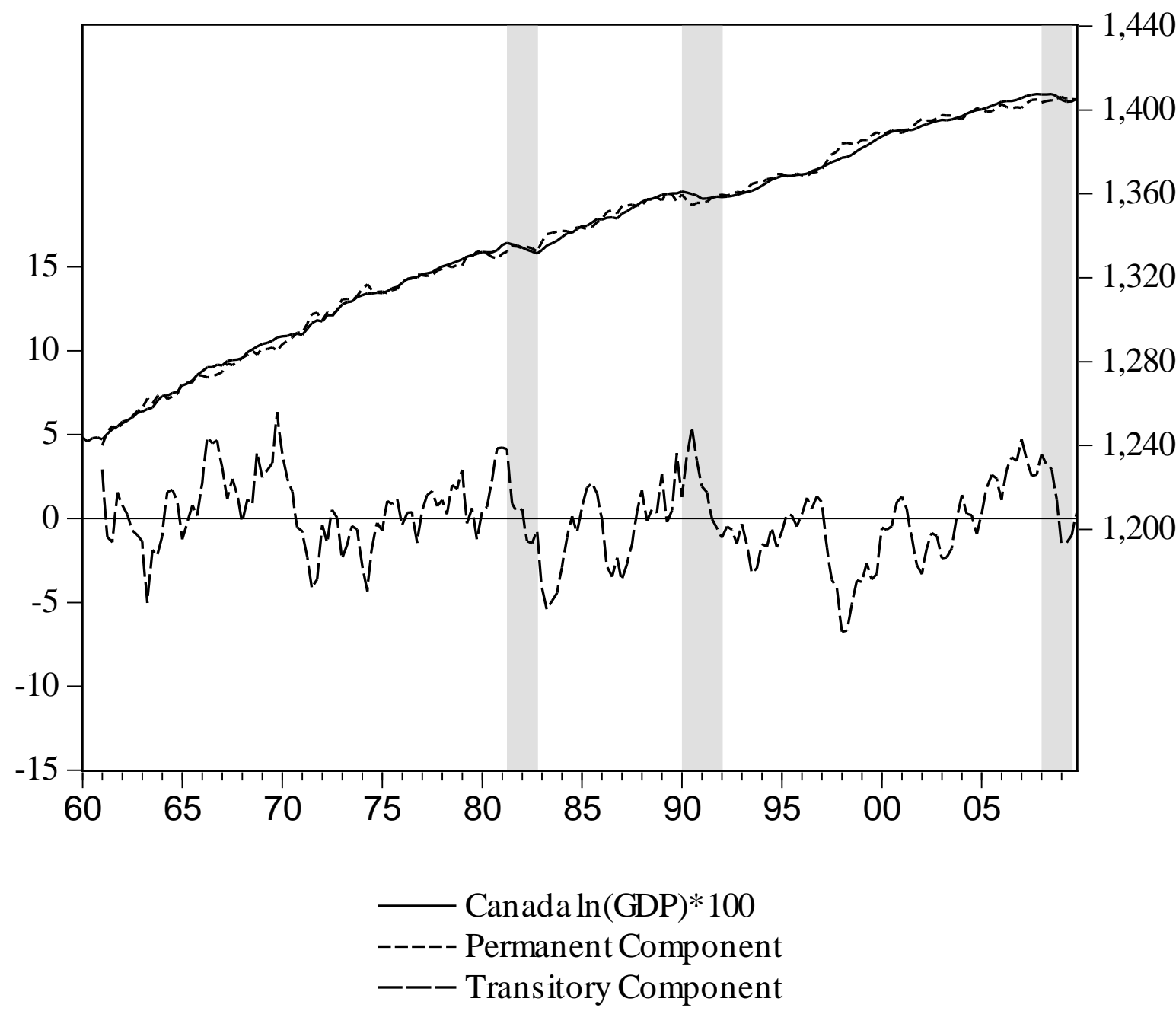

\footnotetext{
${ }^{14}$ Shaded areas represent business cycle peak to trough dates based on the Economic Cycle Research Institute (ECRI) except for the U.S. where the dates come from the National Bureau of Economic Research (NBER).
} 


\section{Panel 2: France}

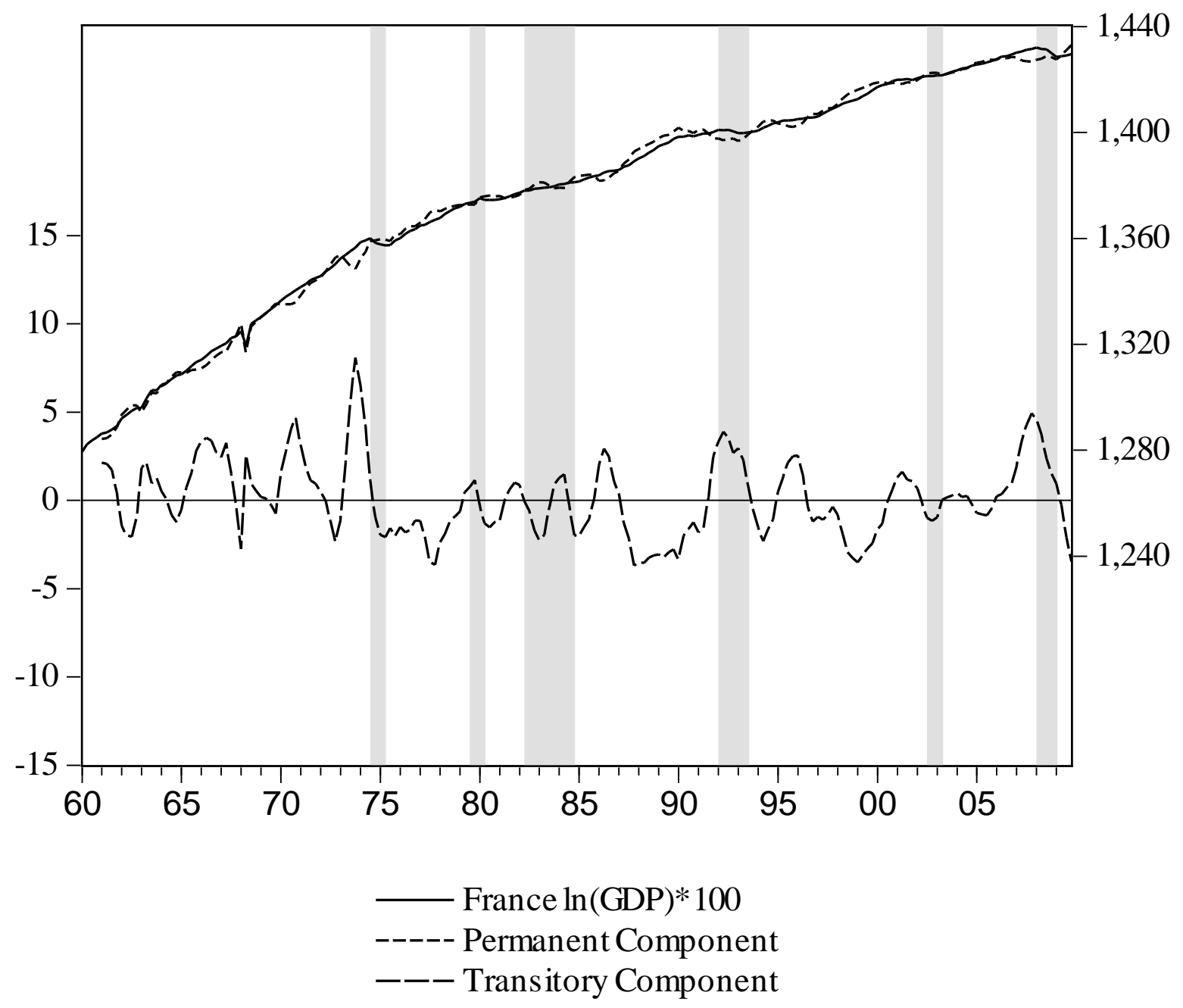




\section{Panel 3: Germany}

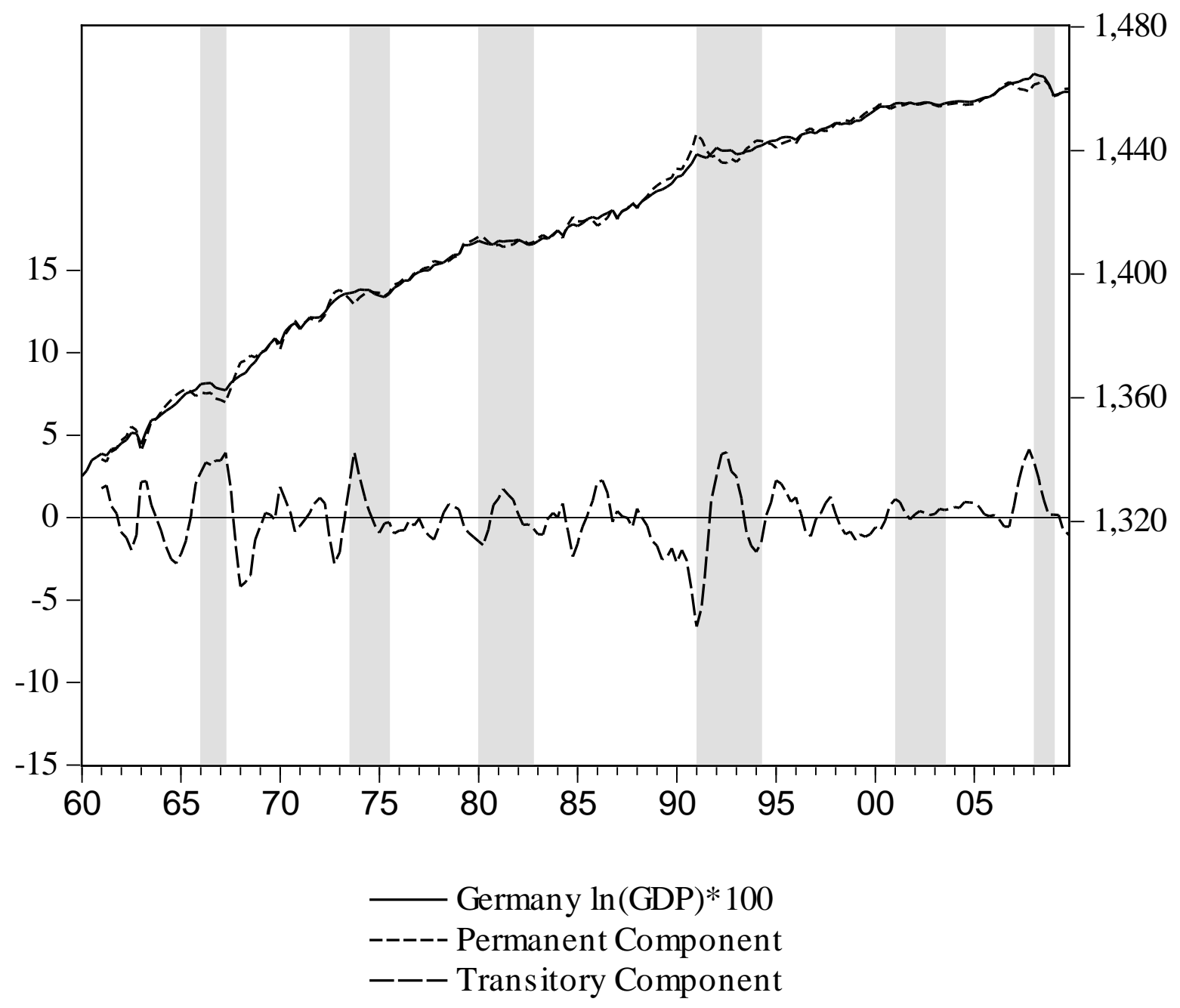


Panel 4: Italy

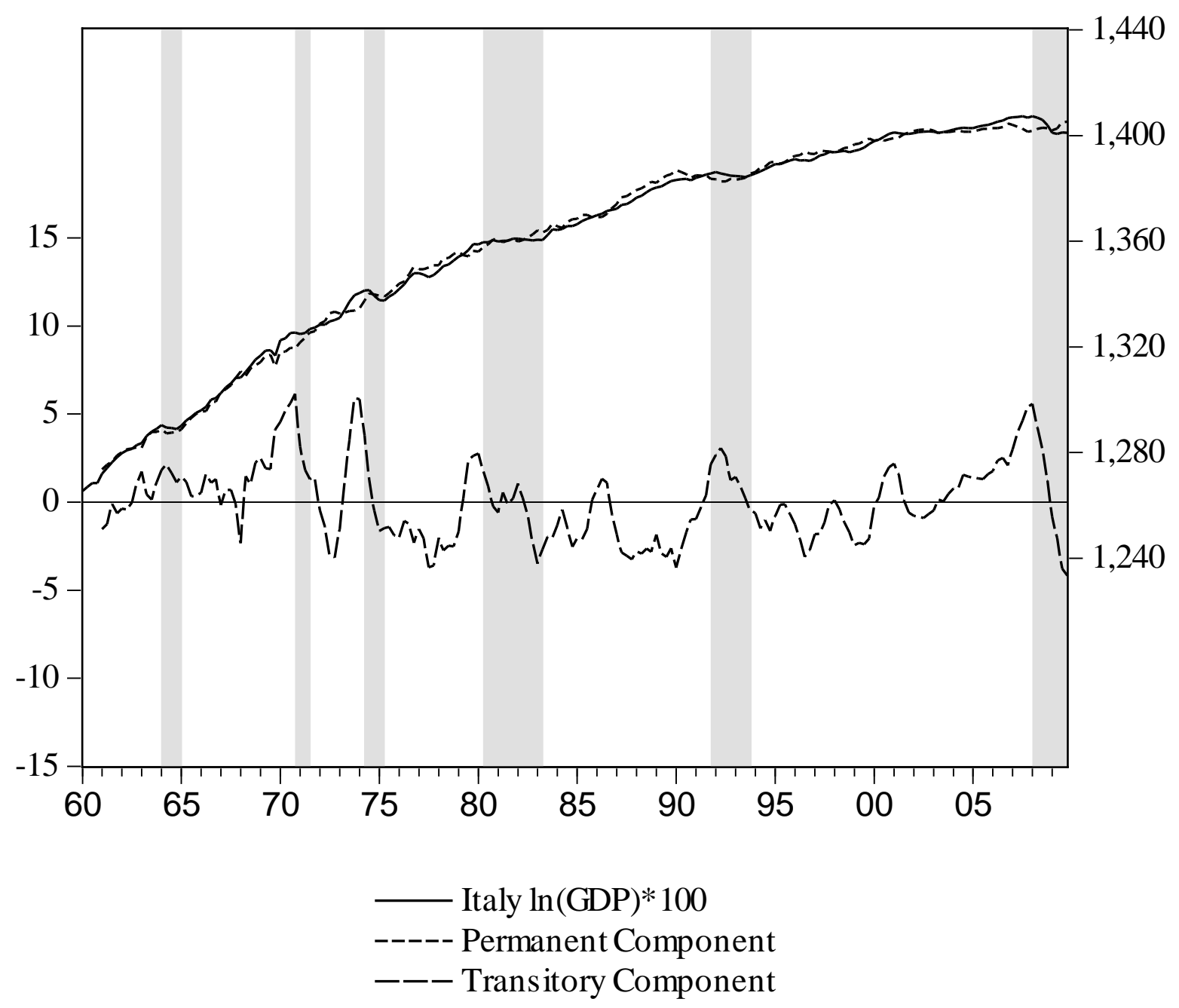


Panel 5: Japan

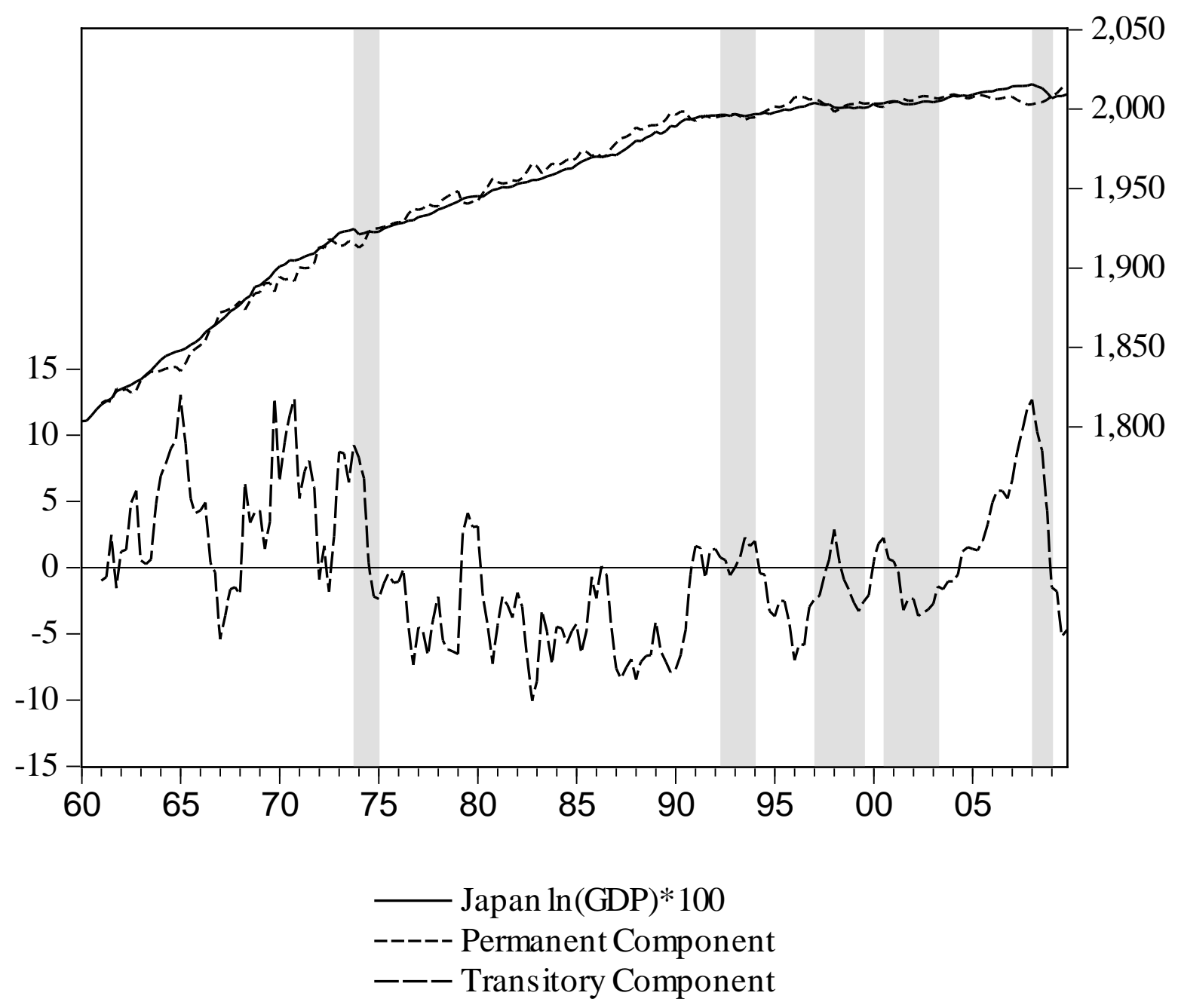


Panel 6: U.K.

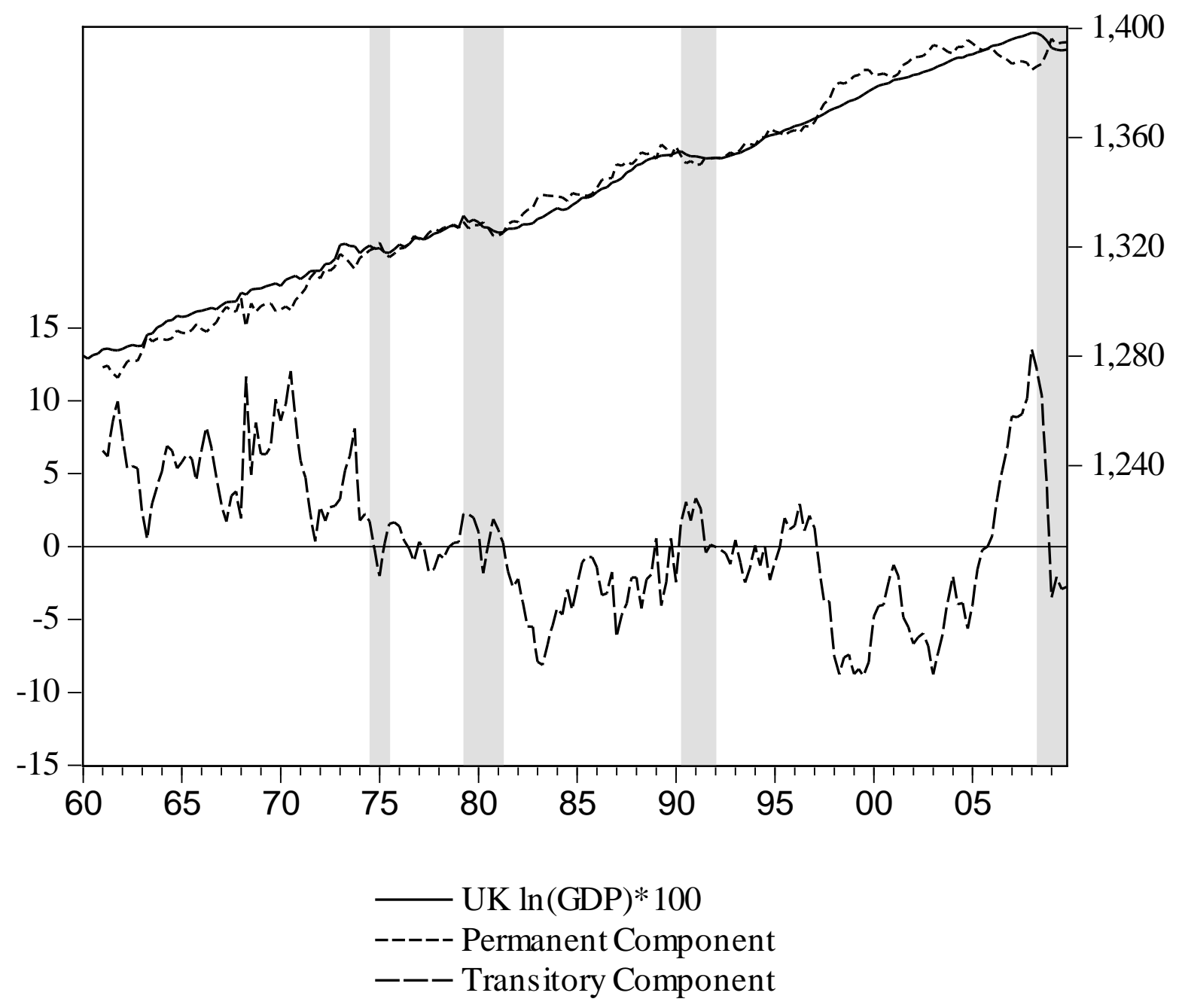




\section{Panel 7: US}

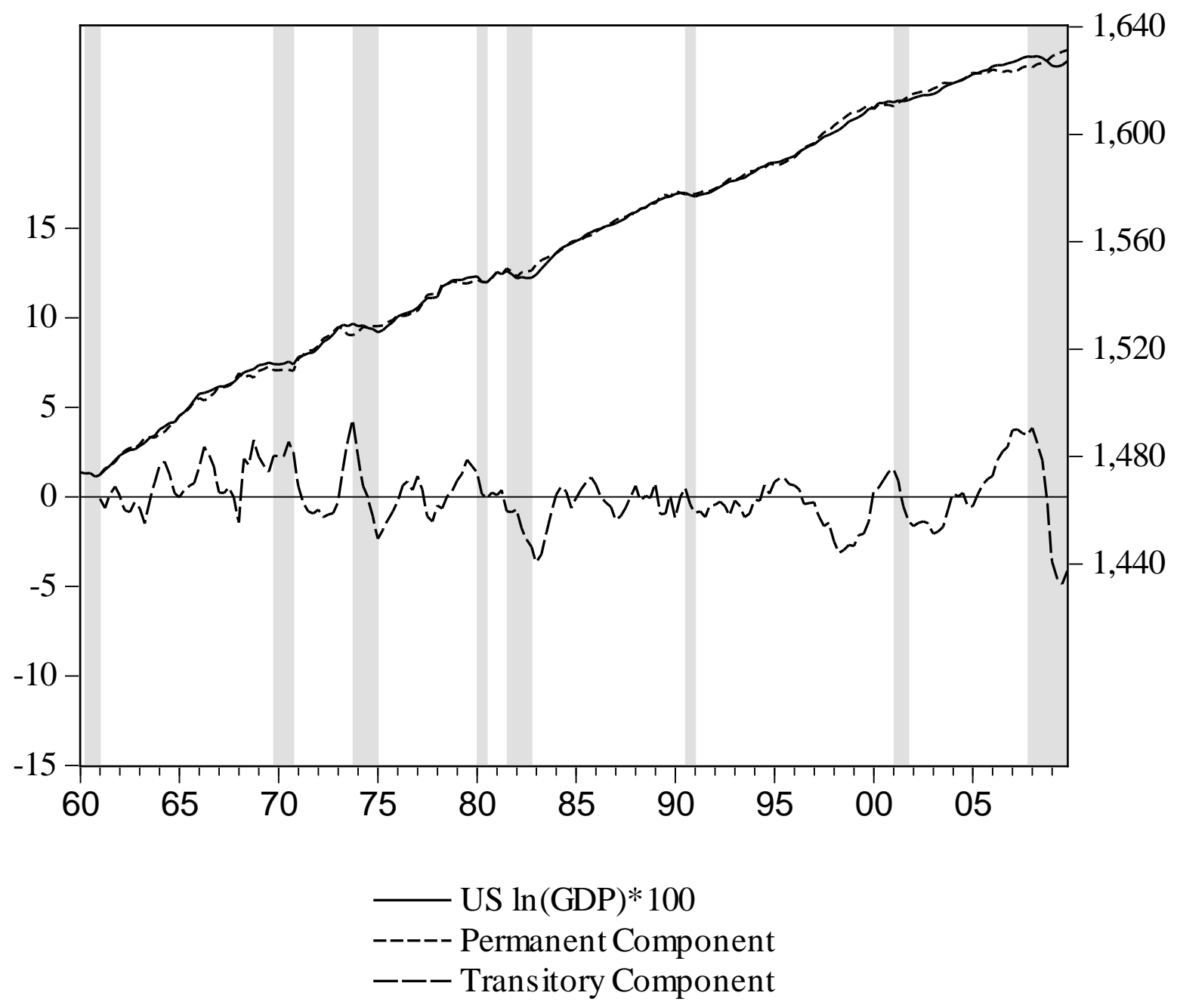


Figure 2: Transitory Components 2005 - 2009

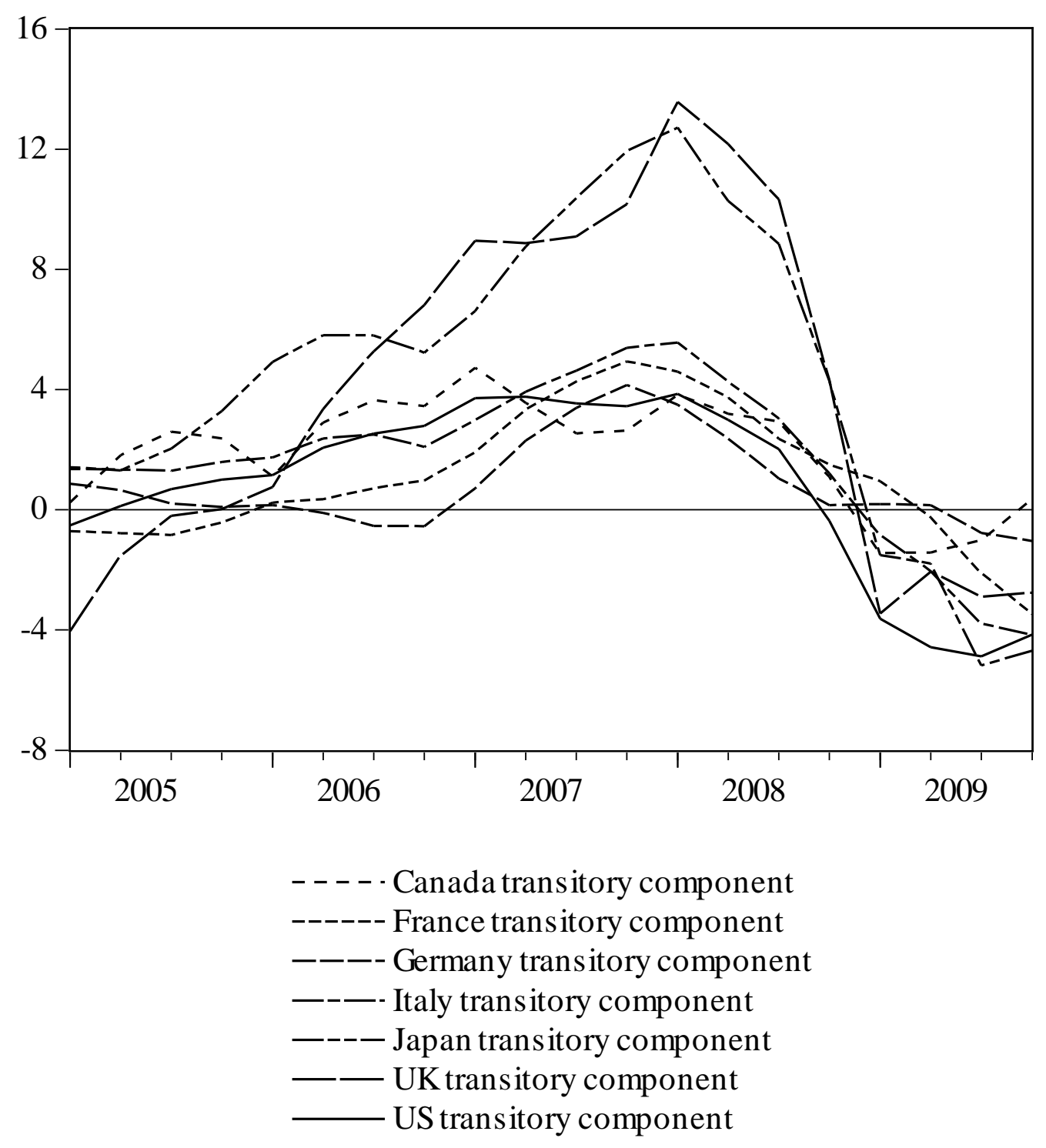

